\title{
Un tratado inédito sobre la idea de nobleza atribuido a Francisco de Rades y Andrada ${ }^{1}$
}

\author{
Arsenio Dacosta Martínez \\ Universidad Nacional de Educación a Distancia \\ adacosta@zamora.uned.es \\ Carlos Mota Placencia \\ Euskal Herriko Unibertisitatea \\ carlos.mota@ehu.es
}

Recepción: 26/04/2014, Aceptación: 16/10/2014, Publicación: 17/12/2014

\begin{abstract}
Resumen
Se presenta en este artículo una edición y comentario de lo que parecen ser los capítulos iniciales de un tratado sobre la idea de nobleza (y sobre la definición de determinados conceptos relacionados con esta) atribuido a Francisco de Rades y Andrada, cronista de las órdenes militares. El texto, escrito antes de 1599, figura en un manuscrito de la Biblioteca Nacional de España en la significativa compañía de varios textos relacionados con la genealogía e historia de la familia Sarmiento (la del dedicatario del tratado, don Diego Sarmiento de Acuña) y de copias renacentistas de dos textos medievales muy importantes en la historia de la reflexión de nobilitate en España: la traducción castellana de un famoso discurso pronunciado por Alonso de Cartagena en el Concilio de Basilea en 1434 y la versión castellana del Príncipe de Viana del De vera nobilitate de Buonaccorso de Montemagno (escrito originalmente ca. 1429 y traducido al italiano por Angelo Decembrio para el Marqués de Santillana). Estos, junto con una relación de los caballeros de Calatrava ingresados en la orden entre 1535 y 1595 que podría ser un material complementario de la Crónica de las órdenes militares (1572), resultan ser materiales muy congeniales con las actividades y actitudes de Rades como historiador, muy apegado a la legislación y los documentos medievales y a las enseñanzas filosóficas e históricas derivadas de su frecuentación y un tanto desdeńoso con los abusos y fantasías eruditas de buen número de nobilistas del siglo XVI.
\end{abstract}

1. Este artículo se enmarca en el proyecto de investigación HAR2013-44093-P De la lucha de bandos a la hidalguía universal. Transformaciones sociales, politicas e ideológicas en el País Vasco (siglos $X I V-X V I)$ del Ministerio de Economía y Competitividad del Gobierno de España, y en los trabajos del Grupo consolidado IT-600-13 del Gobierno Vasco. 
Palabras clave

Francisco de Rades; nobleza; terminología

\begin{abstract}
An unpublished Treatise on the Idea of Nobility attributed to Francisco de Rades y Andrada This article presents an edition and commentary of what appears to be the opening chapters of a treatise on the idea of nobility (and the definition of several concepts related to it) attributed to Francisco de Rades y Andrada, chronicler of the military orders. The text, written before 1599, is contained in a manuscript of the National Library of Spain in the company of several significant texts related to the genealogy and history of the Sarmiento family (that of the dedicatee of the treatise, don Diego Sarmiento de Acuña ) and Renaissance copies of two medieval texts quite relevant in the history of reflections on nobility in Spain: a) the Spanish translation of a famous speech by Alonso de Cartagena at the Council of Basel in 1434; b) the Spanish version by Charles, Prince of Viana, of De vera nobilitate (written by Buonaccorso da Montemagno ca. 1429, translated into Italian by Angelo Decembrio for Íñigo López de Mendoza, Marqués de Santillana). These, together with a list of Knights of Calatrava admitted to the order between 1535 and 1595, could be supplementary material for Rades' Chronicle of the Military Orders (1572), and look very congenial with the activities and attitudes of Rades as historian: always faithful to legislation and medieval documents and contemptuous of the fantasies and philological and historical inaccuracies frequently found in SixteenthCentury Spanish writers on the concept and implications of nobility.
\end{abstract}

\title{
Keywords
}

Francisco de Rades; nobility; terminology

El Tratado qué cosa es nobleza, noble, hijodalgo, infanzón y caballero, atribuido a Francisco de Rades y Andrada, se ha transmitido en los folios 91r-97v del ms. 8631 de la Biblioteca Nacional de España (en adelante, BNE), miscelánea historial fechable en los aledaños de $1600 .^{2} \mathrm{El}$ texto, inédito hasta donde hemos podido averiguar, parece un fragmento de un tratado más extenso que o bien se ha perdido o bien el autor no lo llegó a completar. Consta de dos capítulos,

2. Para una descripción de los elementos que componen la miscelánea, véase abajo, en Apéndice, el apartado A. El contexto del Tratado. 
el segundo de los cuales apenas está iniciado en el manuscrito. Sin embargo, culmina con una escueta dedicatoria: "Para don Diego Sarmiento de Acuña», como Rades caballero de la Orden de Calatrava, quien sería embajador español en Inglaterra y, a partir de 1612, Conde de Gondomar.

El fragmento incrementa la producción conocida de Rades y Andrada, capellán de Felipe II, reputado como historiador por su Crónica de las tres Órdenes de Cavallería de Sanctiago, Calatrava y Alcantara, en la qual se trata de su origen y sucesso, y notables hechos en armas de los maestres y cavalleros en ellas, y de muchos señores de título y otros nobles que descienden de los maestres, y de muchos otros linajes de España (Toledo, Juan de Ayala, 1572). No fue la única obra que Rades entregó a la imprenta: publicó también un Catálogo de las obligaciones que los comendadores e cavalleros, priores y otros religiosos de la Orden y Caballería de Calatrava tienen en razón de su ávito y profesión (Toledo, Juan de Ayala, 1571), y es coautor, con frey Álvaro de Luna y Mendoza, de unas Definiciones de la Sagrada Religión y cavallería de Sancta María de Montesa y Sanct Jorge, fliación de la inclita milicia de Calatrava, impresa en Valencia (Pedro Patricio, 1575 y 1589), y escrita a raíz de una visita de inspección al priorato de Montesa llevada a cabo por los autores en 1573. Además de estas obras, se atribuye a Rades una Genealogía de los Ponce de León manuscrita (Madrid, BNE, MS. 11596, fols. 138r-161v), fechada en Toledo el 18 de enero de 1598, dato que apunta - aunque no de forma incontrovertible - a que siguió escribiendo casi hasta el fin de su vida, acaecido el 7 de septiembre 1599. Esto era difícil de deducir de otro modo, pues todas sus obras impresas datan de la primera mitad de los ańos setenta del siglo XVI, esto es, de casi treinta años antes. Los dos capítulos del Tratado qué cosa es nobleza... no forman parte de ninguna de sus obras conocidas, aunque hay concomitancias entre estos capítulos y varios pasajes del Catálogo de las obligaciones, la obra de publicación más temprana. Por eso, fundamentalmente, resulta incierta la fecha de redacción del Tratado.

Los historiadores de nuestros días no se han ocupado mucho de la figura de Rades y Andrada. Es excepción a esto Derek W. Lomax, que le dedicó el estudio que precede a la edición facsímil de la Crónica de las órdenes militares, publicada en 1980. El hispanista británico resalta el rigor documental y el espíritu crítico del freile calatravo, así como la sobriedad de su estilo literario y, como es lógico, se centra en el análisis de su obra más importante. ${ }^{3}$ De hecho, no se refiere más que a una de las otras dos obras publicadas (el Catálogo de las obligaciones...) y no parece haber tenido noticia del Tratado que nos ocupa ni de la supervivencia de la Genealogía de los Ponce de León, tal vez porque Nicolás Antonio la mencionó como «MS. quam vidit D. Thomas Tamaius», ${ }_{4}^{4}$ atribuyendo asimismo a Rades un Nobiliario manuscrito que habrían manejado Tomás Herrera y el propio

3. Véase Lomax (1980).

4. Nicolás Antonio (1783: 464). 
Tomás Tamayo de Vargas. Es conocido, por lo demás, que la crónica de las órdenes militares ha sido explotada por numerosos historiadores posteriores, y que Marcelino Menéndez Pelayo, Francisco López Estrada y otros estudiosos han señalado la importancia de la misma como fuente de Lope de Vega, particularmente en Fuente Ovejun $a^{5}$ y en la mucho menos conocida El sol parado. ${ }^{6}$

Fuera de Lomax y de los mencionados historiadores de la literatura hemos de reseñar que Juan Antonio Guillén Berrendero, en su tesis doctoral, defendida en 2009, dedica unas pocas líneas al Tratado. Para este autor:

En este tratado se siguen, básicamente, los argumentos de [Ferrán] Mexía y de Jerónimo Padilla, autor de un Nobiliario que no vio la luz, pero que gozó de cierto predicamento entre los nobilistas y genealogistas. ${ }^{7}$

Creemos que la afirmación requiere de algunos matices, pues el texto de Rades expone en su mayor parte una idea de nobleza muy bartolista (por Bartolo de Sassoferrato), centrada en la virtud y el libre albedrío, y, por consiguiente, distante de los postulados basados en la preponderancia del linaje y la pureza de sangre que subraya Ferran Mexía, como ha puesto de relieve con especial claridad Carlos Heusch en un amplio estudio sobre este prosista y poeta y su Nobiliario vero (Sevilla, 1492). ${ }^{8}$ No es que Rades oblitere la sangre y el linaje en su concepto de nobleza (¿cómo podría hacerlo un miembro destacado de una orden militar tan implicado en cuestiones legales y administrativas, y, en particular, en el examen de candidatos al ingreso en la misma?). ${ }^{9}$ Sin embargo, Rades llega a una especie de síntesis superadora de la preponderancia de la sangre en que insistieron los principales tratadistas del xv, así, en particular, Juan Rodríguez del Padrón, en su Cadira de honor, y Ferrán Mexía (frente a otros como, muy especialmente, Diego de Valera).

5. Sobre Rades como fuente de información histórica del Fuenteovejuna de Lope de Vega, véase Menéndez Pelayo (1949: 172-174); López Estrada, en Vega y Carpio, Lope de, Fuenteovejuna, pp. 157-160; Kirschner (1980) y Herrera Montero (1989). Un buen resumen en McGrady (1993: 9-10; en las pp. 157-161 se transcriben los concretos fragmentos de la Crónica de Rades que inspiraron la obra del Fénix). Sobre la cuestión de la presencia de la historia de las órdenes militares en la obra de Lope debe verse Rozas (1990).

6. El sol parado se publicó en 1622, en la Decimaséptima parte de las comedias de Lope (en Madrid, por la viuda de Fernando Correa, en casa de Miguel de Siles, 1622). Morley y Bruerton (1968: 258), a juzgar por los metros empleados, la consideran escrita entre 1596 y 1603.

7. Guillén Berrendero (2009: 278, n. 629).

8. Véase Heusch (2009).

9. La implicación de Rades en estas cuestiones queda claramente de manifiesto en el Catálogo y en las Definiciones. Véase, además, Lambert-Gorges (1982); y Fernández Izquierdo (2005). Aborda esto mismo in extenso, y de forma estrechamente relacionada con lo que nos ocupa, la tesis doctoral de Guillén Berrendero (2009: 204 y ss). Para las probanzas de hidalguía, véase además Morell Peguero (1978). 
Como apuntábamos, el contenido del texto de Rades es expresamente un ensayo de definición y revisión — «conviene primero declarar bien...»— de los principales conceptos que parecen afectar a un ensayo más amplio centrado quizá en la historia de la hidalguía española, a saber, "qué es noble, hijodalgo, infanzón y caballero». Sospechamos de ese carácter histórico por cuatro razones fundamentales: las alusiones a la temática histórica presentes en el texto, la expresa referencia a un capítulo posterior dedicado al «gran Conde don Sancho García, señor de Castilla» en relación a la hidalguía que parece iniciado al final del texto conservado y, por el hecho de que Rades sea, a diferencia de otros nobilistas, un historiador. Y por su expresiva declaración de principios: «Yo no pretendo escribir particular tratado de la nobleza, ni hay necesidad dél [...]. Más para mi historia estoy obligado" (la cursiva es nuestra).

El texto de Rades presenta un tono eminentemente didáctico, no exento de afán crítico con aquellas teorías que no consideraba acertadas. Se estructura sobre lo anunciado, esto es, dilucidar los conceptos señalados, aunque esta misión la resuelva de manera diversa, ocupando la mitad del ensayo a la definición — definiciones más bien- de nobleza y prácticamente el resto a la de hidalguía y sus diferencias con el concepto anterior. Las dos restantes - caballero e infanzón - las resuelve en muy pocas líneas: de hecho, para la definición de infanzón nuestro autor apenas utiliza 27 palabras. El resultado general es, en consecuencia, muy poco uniforme, aunque no tanto por la extensión de cada definición como por el contenido, por el número de referencias y por el tipo de discurso empleado en cada una. Tras su intento de dilucidar tales conceptos, el autor vuelve a la cuestión de los orígenes de la hidalguía en Castilla, en lo que parece el inicio de un capítulo de carácter claramente histórico. Rades parece conocer bien las fuentes medievales - especialmente las leyes castellanas sobre la materia- y a sus contemporáneos, compartiendo a nuestro juicio importantes paralelismos en este sentido y en el del tono general con la obra de Andrés de Poza, con las oportunas salvedades dadas las enormes diferencias de extensión y desarrollo de ambos trabajos. ${ }^{10}$

Como decimos, es la definición de nobleza la que inicia el ensayo de Rades y ocupa buena parte del mismo. Sin apenas preámbulo, Rades recoge la explicación etimológica del término noble a partir de las divulgadas teorías de Bartolo da Sassoferrato recibidas en la Castilla del xv por Diego de Valera, entre otros, y bien conocidas por la tratadística española contemporánea de Rades ${ }^{11}$ a partir

10. Con el objetivo de contestar a Juan García de Saavedra, Andrés de Poza elaborará su Ad pragmáticas de Toro \& Tordesillas, sive de nobilitate in proprietate (1589), ahora accesible en edición de Muñoz de Bustillo (1997).

11. La bibliografía sobre la materia que aquí nos ocupa es tan abundante como sólida. Sólo a modo de introducción, véanse: García Hernán (1993: en especial, 507-512); Carrasco Martínez (2004); Soria Mesa (2007) Menéndez Pidal (2008). Como obra de referencia principal remitimos al ya citado Guillén Berrendero (2009: especialmente, 25-132). 
de los textos medievales castellanos del mismo género, ${ }^{12}$ del influjo italiano, ${ }^{13}$ y de las obras del jurista francés André Tiraqueau, entre otros. ${ }^{14}$ Esta primera definición de nobleza — presente en otros tratadistas contemporáneos, como Juan Benito Guardiola — ${ }^{15}$ está ciertamente acorde con su fuente latina — noscibilis - aunque bien es cierto que además de fama, el término nobilitas es usado en el latín clásico con significados como 'altanería' (Plauto) además, obviamente, del valor propiamente sociológico del término (Cicerón, Séneca). A la canónica explicación, Rades parece añadir algo de su cosecha, esto es, la alusión a la epístola de San Jerónimo contra Helvidio, que poco aporta al fondo del asunto. En resumen, Rades nos ofrece una primera definición de nobleza como equivalente a fama que, «en su entera y propia significación, se toma en buena parte y en mala». Fuera de lo canónico del recurso cabe preguntarse si la cuestión de la "pública fama» no preocupaba a Rades en un sentido más práctico y cercano, esto es, en su experiencia personal como caballero de una orden militar en la que uno de los criterios de acceso era la conocida fama del linaje del candidato. ${ }^{16}$

El esfuerzo por definir el concepto de nobleza, quizá no del todo grato para Rades — «...ni hay necesidad dél»—, se complica en su texto al tratar de resumir las distintas acepciones del mismo sin precisar claramente los distintos niveles conceptuales y discursivos a los que se enfrentaba. De ahí que, de la etimología, Rades pase a la delicada cuestión de la igualdad originaria de todos los hombres en la incontestable autoridad del libro del Génesis o de San Pablo, resuelta desde la tratadística medieval en atención a la virtud personal. ${ }^{17}$ Rades eleva sobre la cuestión dos argumentos. El primero de ellos alude a una cuestión natural: «la virtud de algunos y vicio de otros». El segundo lo expresa con una cita latina que pone en boca de un impreciso "profeta». La cita era muy conocida en su época ${ }^{18}$ y alude a la cuestión de la virtud personal —y su carencia- en relación

12. Para esto es referencia inexcusable Rodríguez Velasco (1996).

13. Para la tratadística italiana de la nobleza en el Cuatrocientos, en la que destaca especialmente el De nobilitate de Poggio Bracciolini, véase Rabil (1991), y Finzi (2010).

14. Muy especialmente, su influyente Comentarii de nobilitate et iure primogenitorum (París, apud Iacobum Keruer, 1549). Sobre la recepción de Tiraqueau en España, véase Guillén Berrendero (2009: 61-62). Una panorámica bien trabada en Carrasco Martínez (2008).

15. Tratado de la nobleza y de los titulos y ditados que hoy tienen los varones claros y grandes de España, Madrid, por la viuda de Alonso Gómez, 1591. Para este autor remitimos a Guillén Berrendero (2002) y (2004).

16. Para esta cuestión véanse Lambert-Gorges (1982) y Fernández Izquierdo (2005). Aborda esto mismo in extenso y de forma estrechamente relacionada con lo que nos ocupa la tesis doctoral de Guillén Berrendero (2009). Para las probanzas de hidalguía, véase Morell Peguero (1978).

17. Sobre el partícular, véase Carrasco Martínez (2004).

18. Es el ejemplo del ex libris del médico suizo Anton Schneeberger (1530-1581) expresado en estos términos: «Si pater est Adam cunctis, si mater est Eva, / Curné [sic] omnes omnes sumus nobilitate pares? / Degenerant homines vitiis, fiuntque minores, / Exaltat virtus nobilitatque genus». Sobre este ex libris, véase, Fechner (1988: 205). 
a la herencia y linaje, cuestión muy debatida entonces ${ }^{19}$ y sobre la que volverá en el texto. El origen de la sentencia latina que recoge Rades es muy difuso, y si Rades la atribuye a un "profeta», otros tratadistas posteriores lo harán a «un oltro anonimo poeta». ${ }^{20} \mathrm{La}$ cita se atribuye comúnmente a André Tiraqueau, quien ya incluye el tema en su De nobilitate et iure primogenitorum, ${ }^{21}$ aunque el planteamiento es, sin duda, medieval, pues ya se encuentra en la Castilla del siglo XV en un pasaje de la descripción de Roma contenida en las Andanças e viajes de Pero Tafur:

Están en Roma dos estatuas, e diçen que fue qüistión entre los villanos e fidalgos, diçiendo los villanos que ¿por qué razón, seyendo fijos de un padre, es a saber, Adán, e por consiguiente Heva madre, que por qué los fidalgos los avían de preçeder? E dize el villano en unas letras que tiene entalladas: Cum pater Adam nobis sit, mater Eva, cur igitur non sumus nobilitate pares? Respondió el fidalgo e dixo: Degenerant omnes viciis, fiuntque minores, exaltat virtus, nobilitantque mores. E de allí se diçe los fidalgos quedar con mayor juredicçión, e aun se diçe que aquella fue la cabsa por do se fizo la ley que ningún villano ni muger non pudiese aver consulado, la qual después fue quebrada quando propuso en el senado Gayo Mario, segunt Salustio lo diçe. ${ }^{22}$

Después recurrirán a él otros tratadistas españoles como Lope de Isasi.

Si la primera definición de nobleza que ofrece Rades nos sitúa en el ámbito conveniente — pero peligroso - de la etimología, la identificación de inspiración aristotélica entre virtud y nobleza nos lleva a un nivel bien distinto, el de la filosofía moral. Es un terreno en el que nuestro autor no parece cómodo, por lo que recurre a la autoridad — esta vez sí citada expresamente - del «famoso y excelente jurisconsulto Bartolo», consignando en nota al margen la llamada a su De dignitatibus. ${ }^{23} \mathrm{La}$ tarea en la que pretende ocuparse Rades no es otra que la de la distinción tomista entre los distintos tipos de nobleza, algo que añade un nuevo —y quizá inútil— prisma a la cuestión: el teológico. Según Sassoferrato —y Rades tras él一 hay «tres especies de nobleza»: la «teologal o sobrenatural», «la natural y moral», y la "política o cevil». En su resumen, Rades señala las principales características de los tres tipos de nobleza, ciñéndose al esquema preestablecido de deter-

19. Sobre ella, véase Carrasco Martínez (1998).

20. Troyli, Placido (O.Cist). Istoria Generale Del Reame Di Napoli. Tomo Quarto, parte quarta, libro XX, Nápoles, 1750.

21. De nobilitate et iure primogenitorum. París, 1549 , capt. $4, n^{\circ} 6$.

22. Andanças e viajes de... Pero Tafur, p. 36 (del facsímil de la edición de Marcos Jiménez de la Espada), y véanse, en el mismo volumen, la nota al respecto de este pasaje de José Vives Gatell, quien señala que «si las inscripciones que copia Tafur estaban realmente grabadas en dichas estatuas [esto es, las de Pasquino y Marforio], como él parece afirmar, serían las primeras «pasquinate» conocidas» (p. 93).

23. Recogido en sus Opera omnia. Venecia, 1591-1602, t. VIII. 
minar la fuente última de cada una de ellas, o lo que es lo mismo, jerarquizándolas. La nobleza teologal — una suerte de virtud espiritual — tiene, por descontado, su origen en Dios y es la superior de las tres. La nobleza «natural» aclara Rades que «no es, como algunos piensan, la heredada del padre y abuelo que llamamos hidalguía", sino una suerte de nobleza moral que claramente tiene su fuente en el libre albedrío del hombre como evoca una oportuna alusión a un pasaje del De libero arbitrio de San Agustín. Este tema redunda en la cuestión de la virtud, ejemplificándose todo con el expresivo caso de Caín y Abel, pero también citando a Demócrito. ${ }^{24}$ Finalmente, el tercer tipo de nobleza, la "política», es la que dimana de la cúspide social, esto es, del rey, fuente de autoridad. Ni el esquema tomista ni la expresa alusión a Platón — «filósofo sapientísimo»— oculta que Rades es, ante todo, historiador. El discurso sobre la «nobleza natural» es enriquecido con la máxima autoridad posible — al menos para un castellano - sobre la materia nobiliaria, Alfonso X. Las Partidas (II, 9, 6) se erigen, junto a las Decretales, como fuente de derecho - regia, papal - pero también como fuente para una nueva acepción o matiz respecto de la naturaleza de la nobleza. Así, redundando en la cuestión de la virtud, estas fuentes ofrecen a Rades un nuevo argumento: la bondad como paso previo a la virtud —asunto sobre el que volverá- y ésta, a su vez, de la nobleza «natural», todo ello en la línea de transmisión de la ética aristotélica de tan fuerte implantación en la Castilla del siglo xv con Pedro de Osma y Alonso de Madrigal, el Tostado, como grandes referentes. ${ }^{25}$ Todo ello para concluir, con «Casaneo» - Barthélemy de Chasseneuz, del que cita su Catalogus gloriae mundi, publicado en 1529- que la "verdadera nobleza» no es otra que la que otorga la virtud, argumento que literalmente hallamos también en Arce de Otálora y en la tratadística del siglo XvII. ${ }^{26}$

Así llega Rades al tercer tipo tomista de nobleza, la "política o cevil», recurriendo de nuevo a fuentes medievales - Sassoferrato, Valera-, pero también a Alfonso X (Partida II, título XXI), aunque sin citarlos expresamente. No obstante, la inspiración es evidente. Según la obra legislativa de Alfonso X, la nobleza puede adquirirse por tres vías: «la una por linaje», «la otra por saber», $\mathrm{y}$ «la terce-

24. Podría estar en relación con un tratado de nobleza contemporáneo al de Rades, obra de Antonio López de Vega, Heráclito y Demócrito de nuestro tiempo (1594). Sobre este autor, véase Acquier (2000). Guillén Berrendero (2009: 85, n. 123) por su parte, reivindica que «la obra de López de Vega debe ser inserta de manera inequívoca dentro de los discursos de la identidad nobiliaria, y no en otro lugar».

25. Para Pedro de Osma, véase su Comentario a la Ética de Aristóteles; de Alonso de Madrigal, sus Cuestiones de Filosofía Moral.

26. «Vera nobilitas est virtus» escribe Arce de Otálora en su Summa nobilitatis hispanicae, f. 189r (citado por Guillén Berrendero 2009: 41). La cuestión de la virtud personal del noble por encima de la del linaje seguirá siendo una preocupación de los tratadistas del siglo XviI, caso de la Condesa de Aranda, Luisa María de Padilla, que redacta sus Lágrimas de la Nobleza bajo este prisma (Zaragoza: Pedro Lanaja, 1639). Tratan sobre esta obra y sobre la cuestión de fondo in extenso Egido (1998), y Cárceles de Gea (1989). 
ra por bondad de costumbres o de maneras». ${ }^{27}$ La versión de Rades difiere poco de lo anterior, simplemente recalca que «emperadores, reyes y otros príncipes pueden dar nobleza cevil y política», y también quitarla, como argumentará más adelante nuestro autor.

Desde un punto de vista moral, esta es «la tercera y más ínfima especie de nobleza de todas las tres arriba declaradas» y su fuente última es la «merced del rey» o la "sangre o linaje», remitiendo de nuevo en este último caso a la autoridad de reyes (pasados). Vuelve Rades en este punto a la digresión sobre la virtud y la nobleza, recurriendo a autores clásicos como Boecio, Ovidio y Juvenal, que enlazan directamente a autores medievales como el Marqués de Santillana o el Canciller Ayala con la tratadística española del Quinientos. Todo se resume, de nuevo, traduciendo Rades las palabras de Juvenal, en que «solamente la virtud es la verdadera y única nobleza».

Mediado el texto, Rades cree oportuno introducirse en el segundo concepto, el de hidalguía, que, a juzgar por la inconclusa segunda parte, parece haber sido uno de los objetos principales de su plan de trabajo. Aún así, le dedica mucho menos desarrollo que al de "nobleza», quizá por ser una cuestión menos contaminada por acreditadas autoridades y más cercana a su experiencia. Es aquí, a nuestro juicio, donde Rades se muestra más original y con una voz más personal. Además, cuenta Rades con una fuente de incontestable autoridad, léase «la [ley] segunda del título veinte y uno, en la Partida segunda» que extracta ampliamente recogiendo dos argumentos sobre el origen del término, el primero de orden filológico y el segundo de tipo histórico. Estas disquisiciones sobre el origen del concepto de hidalguía corren rápidas en la pluma de Rades sobre tamaña autoridad: el término «fijodalgo» significa claramente «fixos de bien», lo que nos remite de nuevo a la «nobleça como bondad». De ahí, el argumento de las Partidas lleva a una nobleza originaria, propia de «los gentiles [que] fueron homes nobles e buenos». El Rades historiador enlaza directamente esta cuestión con la discusión sobre otro posible origen del término «hidalgo», muy extendido en el Quinientos tal y como nos muestra el autor. Juristas y tratadistas como Gregorio López, Ginés de Sepúlveda o Juan Arce de Otálora ${ }^{28}$ creían, según Rades, en un

27. Partida II, 21, 2; y véanse los comentarios al respecto de Carracedo y Abal-Brasón (1989: 491 y ss.)

28. El primero glosó la Partida II en una divulgada edición de 1555 (Salamanca: Andrea de Portonariis). Juan Ginés de Sepúlveda expone esa fantasiosa etimología de la palabra hidalgo en un pasaje de una epístola dirigida al príncipe Felipe: «Erat autem antiquitus Pax Augusta non solum romanorum colonia, sed etiam conventus, ut Emerita Augusta et utraque civitas iuris italici, ex quo iure Italici, vocabulo ad immunitatem pertinente, dicebantur, unde Italici, deinde idalgi et hidalgui paulatim corrupta voce nominati sunt» (Citado por Solana Pujalte 1994: 194, y n. 31, donde detalla cómo Arce de Otálora acoge la tesis de Ginés de Sepúlveda). La obra más conocida de Arce de Otálora es su De nobilitatis \& inmunitatis Hispaniae causis (Granada, Xantus et Sebastianus Nebrissensis, 1553), también conocida como Summa nobilitatis Hispanicae (Salamanca, Andrea de Portonariis, 1559). 
argumento falsamente etimológico e insostenible históricamente: el término «hidalgo» derivaría de «itálico» y la hidalguía no sería en el fondo sino un trasunto de un jus italicum ${ }^{29}$ o residuo de la antigua ciudadanía concedida a los hispanos por Vespasiano. ${ }^{30}$

Tres argumentos sólidos despliega Rades contra tal pretensión hipererudita. El primero de ellos es de orden filológico: la derivación itálico>fidalgo no se sostiene desde su experiencia como historiador, confirmando que nunca ha hallado el término $\sin f_{\mathrm{o}} h$ inicial. Es más, Rades nos confirma que en el «grande número de antiguas escripturas» que él ha consultado, el término más antiguo es el de "fidalgo y fixodalgo" mientras que en los documentos más modernos el término figura "con $\mathrm{H}$ al principio».

El segundo argumento ataca la cuestión de la hidalguía como trasunto medieval de la antigua ciudadanía romana en orden a la lógica histórica y a las autoridades de Plinio y Ambrosio de Morales.

Finalmente, Rades zanja la cuestión recurriendo de nuevo a las Partidas, tanto en lo que a la acepción de «algo» se refiere (Partida I, 21, 2) como a la propia definición de «hidalgo" (Partida II, 21, 3), definitiva a nuestro modo de ver en el pensamiento de Rades:

hijodalgo, abreviando el nombre hidalgo, quiere decir hijo de bien, qu'es hijo de hombre de calidad y señalado en estado, señorío, solar antiguo y honroso, haciendas y riquezas bien adquiridas, por las armas o por las letras, o por grandes servicios hechos al rey o a su patria, o por otras honrosas vías.

La cuestión del estatus y la riqueza, clave para entender el significado social de la nobleza en su contexto, apenas queda levemente esbozada en Rades, desde luego muy lejos de lo que expresamente hacen algunos de sus contemporáneos. Es el caso de Sebastián de Covarrubias quien, no mucho después de Rades, identifica claramente «ser hijo de algo» con poseer «hazienda y quantía heredada de sus passados y ganada, no en mercancías, tratos, ventas y compras, sino de los gages y mercedes de sus reyes hechas a ellos y a sus passados, conservándolas y transfiriéndolas de uno en otro sucessor». ${ }^{31}$

La cuestión de la hidalguía será retomada al final del texto, en lo que parece ser el inicio del segundo e inacabado capítulo que trata sobre el origen histórico de

29. Alude a la cuestión Haupt (1921: 167-168). Chauchadis y Laspéras (1989: 50-51), que analizan in extenso la cuestión de la etimología de «hidalgo» e «hidalguía» en el siglo XVI, afirman que Arce de Otálora es quien critica a López y Sepúlveda apostando en su caso por la misma acepción que defiende Rades, esto es, el «de algo» equivaldría a «de bien» o lo que es lo mismo calidad natural.

30. Asunto que en el siglo XIX aún tendría eco entre algún tratadista como Bartolomé José Gallardo (véase Vigón 1947: 149).

31. Sebastián de Covarrubias, Tesoro de la lengua castellana, s.v. fidalgo. Y véase Cavaillac (1989: 106). 
la hidalguía castellana. No obstante, esta primera parte sobre la terminología de la nobleza acaba, tal y como estaba anunciado, con las definiciones de «infanzón» y «caballero». La primera no ofrece problema alguno para Rades:

Infanzón, en lenguaje antiguo castellano, es lo mismo que ‘hijodalgo sin título ni estado'. Y aunque ya no se usa en Castilla este nombre, úsase en Aragón. ${ }^{32}$

Tan breve definición es, en esencia, correcta, si bien no aclara el origen del término, ni el abandono del mismo en Castilla desde que en el siglo xiII se comenzara a difundir el de hidalgo. ${ }^{33}$ Sí introduce una cuestión sumamente interesante que apenas deja esbozada: la "grande diferencia entre hidalgo y noble». Ello conlleva una nueva acepción para la categoría de noble, que no es otra que descender de hidalgos por parte de padre y madre. La hidalguía, por el contrario, en atención a las Partidas, basta con que sea heredada solo por parte de padre, «e por hijodalgo se puede contar, mas non por noble». ${ }^{34} \mathrm{El}$ argumento es coherente con lo que expresa el propio Rades en algún pasaje de su obra principal: la nobleza es un estado que transmiten y, también, poseen las mujeres. ${ }^{35}$ Esto choca, no obstante, con una realidad mucho más variada de lo que fijaba la vieja ley alfonsí, al menos para época medieval. Recientemente, Ramón Díaz de Durana ha analizado varios casos en la Álava bajomedieval que demuestran que una de las vías habituales de acceso a la hidalguía habían sido los matrimonios mixtos, cuestión que algunas colectividades pecheras tratan de limitar. ${ }^{36}$

La última definición anunciada por Rades no es otra que la de caballero. Rades recurre de nuevo a una sencilla formulación:

hombre noble o hijodalgo armado caballero por algún rey o en alguna orden de las militares como son las de Santiago, Calatrava, Alcántara, San Juan y otras semejantes. ${ }^{37}$

32. Sobre la infanzonía aragonesa y su conformación definitiva en el siglo XIII, véase Conde y Delgado de Molina (1999).

33. Sobre esta cuestión son clásicos los estudios de Carlé (1961), Lacarra (1975), y Pérez de Tudela y Velasco (1979). Un buen resumen en Díaz de Durana y Otazu (2011).

34. Partida II, 21, 3.

35. Dice así respecto de las comendadoras del Convento de Almagro de la Orden de Calatrava: "concurriendo en ellas las dichas qualidades, de nobleza y limpieza de sangre» (Crónica... Calatra$v a$, p. 83v). La cuestión no es, en absoluto nueva, y se venía planteando de forma especialmente intensa desde tiempos de los Reyes Católicos (no en vano, promotores de la Inquisición en Castilla). Para lo que aquí afecta, es de referencia el estudio ya clásico de Gerbet y Fayard (1982).

36. Véase Díaz de Durana (2004: 228-264). Tampoco podemos olvidar que en 1501 los Reyes Católicos otorgaron un privilegio a la región de Allende Ebro y montañas de Burgos, así como a los seńoríos y provincias vascas según la cual los hijos naturales de los hidalgos merecían también la consideración de hidalgos, asunto recordado entre otros por Juan García de Saavedra en su De hispanorum nobilitate et exemptione sive ad pragmaticam Cordubensem..., publicado en Valladolid, 1588 (sobre el particular, véase Carracedo y Abal-Brasón, 1989: 493-494).

37. Los textos nobiliarios bajomedievales insisten en la consideración noble del caballero, incluso 
De nuevo hallamos en Rades una definición precisa desde el punto de vista histórico complementada - y esto sí es de gran valor - por una apostilla sobre la acepción de caballero «en ordinario lenguaje». Según esta el término se estaría usando para referirse a cualquier titulado, señor o mayorazgo. Es más, dice Rades:

Está ya tan estragado todo esto en el vulgar lenguaje que llaman caballeros a hombres muy ajenos destas calidades por tener buena renta y criados y caballos.

Fuera del valor filológico de la noticia sobre el uso de estos términos al final del Quinientos, la cuestión revela la profunda preocupación de los tratadistas de la nobleza sobre cuestiones como el ennoblecimiento de ciertos grupos urbanos o, incluso, sobre las declaraciones expresas y colectivas de universal hidalguía, o el replanteamiento de la propia función de la caballería desde el final de la Edad Media. ${ }^{38}$

Rades alude a una de estas cuestiones, al menos indirectamente, cuando menciona las "probanzas de hidalguías». Con esta alusión, Rades introduce una digresión — quizá inspirada en Huarte de San Juan — ${ }^{39}$ sobre la cuestión de los quinientos sueldos «de vengar» a los que estaban obligados los hidalgos, dejando de lado cuestiones omitidas como la transmisión femenina de la hidalguía, la limpieza de sangre, la cuestión de los oficios deshonrosos o la hidalguía universal, mientras que la cuestión de la exención fiscal de los hidalgos apenas queda iniciada. Cierto es que, en tiempos de Rades, parece que en las probanzas primaba ante todo la cuestión del solar conocido del pretendiente, ${ }^{40}$ pero esto no justifica que evitara estas otras cuestiones quizá más trascendentales en un ensayo de definición como el suyo.

Ya hemos hecho alusión a la transmisión femenina de la hidalguía. Respecto de la limpieza de sangre, sorprende que, en el manuscrito aquí editado, Rades no parezca preocupado por ella, cuando sabemos que tenía en sus días un protagonismo fundamental en el acceso a las órdenes religiosas y en las abundantes

utilizando expresiones tan esclarecedoras como «caualleros hidalgos» (véase simplemente Ladero Quesada, 1999).

38. "Así pues, en Castilla se recibió la identificación entre caballería y nobleza del exterior y se intentó adaptar, por lo que surgieron dos grupos de tratadistas que se convirtieron en defensores de dos opciones muy diferentes: 1) Aquellos que defendían que la caballería era una dignidad que confería nobleza (siguiendo las teorías de Bartolo de Sassoferrato: Diego de Valera y Rodrigo Sánchez de Arévalo) y 2) aquellos que defendían que la caballería era tan sólo un añadido a la condición nobiliaria de tal modo que sólo los nobles podían ser caballeros (Gutierre de Díaz de Games, Juan Rodríguez del Padrón y Hernán Mexía). En el fondo lo que realmente importaba era saber si el ejercicio militar podía abrir las puertas de la nobleza a un plebeyo y, por extensión, si también lo permitiría el ejercicio de la pluma y el intelecto» (Carceller Cerviño 2006: 696).

39. Véase Chauchadis y Laspéras (1989: 64).

40. Veáse Thompson (1985). Por el contrario, desde finales del siglo Xv en medios como las universidades «more and more treatises on themes like "true nobility" and the relative merits of various studies identified "letters" with literature and the liberal arts», según Elliot van Liere (2000: 79). 
probanzas de hidalguía, y también en la tratadística. ${ }^{41}$ Sorprende más, si cabe, cuando encontramos esta cuestión presente efectiva y recurrentemente en su obra mayor. ${ }^{42}$ Llama igualmente la atención que casi no haga referencia al asunto de la dedicación y el origen del patrimonio noble, con lo que no podemos precisar si Rades era un representante del «discurso conservador de la aristocracia dominante», en palabras de Maravall, ${ }^{43}$ o si, por el contrario, su planteamiento era distinto. ${ }^{44}$ Apenas alude Rades al final del texto a la función originaria de los hidalgos — «si no tuvieren armas y caballo»— ${ }^{45}$ y a trabajar en «algún oficio vil» ${ }^{46}$ ambas causas merecedoras de la reversión de sus privilegios. ${ }^{47}$

Respecto de la hidalguía universal, como decimos, nada menciona Rades de forma expresa, aunque la cuestión puede rastrearse en varias partes de su breve tratado. La alusión al origen adánico es una de ellas, aunque este argumento esté bien lejos de las bases conceptuales y materiales de la hidalguía universal como la cristalizada en el ámbito vasco entre principios del siglo XVI y principios del XVII. ${ }^{48}$ Algo similar ocurre con la alusión a la nobleza originaria de los gentiles o a la extensión del jus italicum. Pero es en la parte final de su ensayo, la que alude a las libertades ganadas del conde don Sancho, la que sí establece la posibilidad del ennoblecimiento colectivo y, sobre todo, y he aquí un argumento recurrente en Rades, que la fuente del ennoblecimiento de naturaleza política hay que buscarla en el rey.

Finalmente, la cuestión de la exención fiscal se relaciona en Rades con las obligaciones de los privilegiados hidalgos — más concretamente, con su responsabilidad civil— desde una perspectiva puramente histórica. Intuimos aquí el plan de una obra inacabada de esta naturaleza. Vuelve el Rades historiador negando

41. Véase al respecto Sáez (1989).

42. Crónica... Calatrava, p. 48v, 56r, 68r, entre otros lugares.

43. Maravall (1972)

44. El discurso aludido se superpone con potencia a las «préoccupations d'une petite noblesse urbaine fréquement frustrée dans ses aspirations», unas aspiraciones sólo aliviadas, según Michel Cavaillac, en una valoración positiva manifestada en el arquetipo literario del «hidalgo mercader» dentro de un clima mercantilista que se respiró — fugazmente - en la Espańa del primer cuarto del siglo XVII (Cavaillac, 1989: 123). Sobre el proyecto de una «nobleza nueva» del Conde-Duque de Olivares, acorde con la apertura mercantilista de su época, véase Cárceles de Gea (1989: 75 y ss.)

45. Sobre la dignitas nobiliar vinculada a una función, cuestión muy presente en las Partidas, en Sassoferrato, en Tiraqueau y en los tratadistas castellanos del siglo xvi, véase Soria Sesé (2006: 296 y ss.) 46. Chauchadis y Laspéras (1989: 57 y ss.) analizan específicamente la preocupación por esta cuestión en algunos tratadistas contemporáneos de Rades.

47. Tampoco alude Rades a otros privilegios que gozaban los hidalgos, como los referidos a la tortura, ya recogidos en las Partidas (II, 21, 24). Sobre esta cuestión, véase el estudio de Martínez Díez (1962).

48. Para esta cuestión remitimos a tres trabajos plenamente complementarios en los que no faltan referencias a tratadistas como Arce de Otálora, García Saavedra, Poza o Guardiola: Fernández Albadalejo y Portillo Valdés (1989), Soria Sesé (2006) y, sobre todo, Díaz de Durana y Otazu (2011). Respecto de la declaración de la universal hidalguía a los naturales de la Provincia de Guipúzcoa, Lourdes Soria plantea que debe adelantarse en algunas décadas respecto de la fecha que maneja habitualmente la historiografía (Soria Sesé 2006: 292 y ss). 
la historicidad del origen de la exención hidalga en Alfonso VIII, y tildando de «no menos fabuloso» otro tipo de explicaciones que remiten al tributo de las cien doncellas de Mauregato, a la batalla «en el Clavijo», y otras «varias fictiones». De nuevo son las fuentes jurídicas - "el Fuero castellano», el Ordenamiento de Alcalá, las Partidas - las que reclama Rades como autoridad incontestable. Aún así, en la parte final de su ensayo, nuestro autor tratará de dilucidar el origen y alcance históricos de la «franqueza y libertades» de los hidalgos castellanos. ${ }^{49}$

Entramos, de hecho, en la parte del tratado que tiene un sentido puramente histórico, comenzando por las fuentes a las que se remite, a saber, Ximénez de Rada, la "Corónica general» y unos indefinidos «historiadores menos antiguos». Todos parecen coincidir en remitir a tiempos del «conde don Sancho, señor de Castilla» la "franqueza y privilegio de no pagar tributo ni servir sin sueldo». La cuestión permite a Rades algunas reflexiones, entre ellas la de que «todos eran pecheros antes deste previlegio y franqueza». Así - y de la mano de su criticismo respecto de viejas leyendas medievales - Rades se muestra totalmente ajeno a las pretensiones de una hidalguía inmemorial de raíz tubalista, goda o de cualquier otra naturaleza, cuando su siglo había sido extremadamente fértil en este terreno. ${ }^{50}$

La segunda conclusión a la que llega Rades es, si cabe, más importante: «claro está que la nobleza, hidalguía y caballería no consiste en no pechar, aunque esta es una de las sus preeminencias después de aquel previlegio». Aunque la razón que parece motivar a Rades es, a nuestro juicio, de concepto - como veremos a continuación-, lo interesante es que la prueba más sólida para este argumento es la existencia de hidalgos y caballeros que tributan, como sucede "en el Andalucía». Rades se muestra aquí sumamente original al dejar la perspectiva conceptual y remitir a realidades contemporáneas en una rica casuística en la que, lamentablemente, nuestro autor no llega a entrar. ${ }^{51}$ Sí menciona la existencia de «algunos lugares destos reinos [donde] no pechan hijosdalgo ni labradores por tener previlegio el mismo lugar para sus vecinos", que creemos que no es difícil identificar con las amplias exenciones de que gozaban comunidades enteras del norte peninsular, desde Asturias ${ }^{52}$ al Pirineo aragonés ${ }^{53}$, con el Señorío de Vizcaya como ejemplo más extremo desde la declaración de la universal hidalguía en 1526.

Repite Rades la existencia de otros lugares «para que los hidalgos pechen por la hacienda que allí poseen», lo que viene simplemente a reseñar la multiplicidad de sistemas fiscales, con sus particularidades y excepciones, en los territorios

49. Exenciones y privilegios concedidos por los reyes castellanos que tienen su principal escenario documentado en el mundo de las villas, particularmente desde el siglo XIII. Para el caso guipuzcoano, véase Martínez Díez (1974).

50. Para el tubalismo —incluido el vasco — véase Caro Baroja (1992: en especial, 49-104).

51. Para la cuestión, véase Soria Mesa (2009: 231 y ss.)

52. Sobre la territorialidad de la hidalguía en algunas zonas de Asturias al final de la Edad Media, véase Carracedo y Abal-Brasón (1989).

53. Un ensayo ya clásico sobre la cuestión en Molinié-Bertrand (1974). 
filipinos de finales del $\mathrm{XvI}^{54}$ o, dicho en palabras de Joseph Pérez «l'exemption fiscale est la conséquence d'un état de fait ${ }^{55}$. No entra Rades, empero, en la liberalidad y extensión de la hidalguía en su tiempo o en la concesión de privilegios de hidalguía universal como los sancionados en 1526 o a los que, un siglo después, recibirán todos los guipuzcoanos. En Rades no se plantea la preocupación, muy de su tiempo, referente al «uso de conceder títulos y privilegios de hidalguía como arbitrio fiscal ... tan frecuente como ponen de relieve las quejas que se repiten en las Cortes de los Reinos en 1563, 1578, 1592, lo mismo que en las de 1617 a 1620, por no citarlas todas» (en palabras de Jorge Vigón). ${ }^{56} \mathrm{La}$ concesión de la hidalguía es, en Rades, histórica y jurídicamente, un privilegio del soberano, y este es, en suma, la fuente principal para la adquisición de nobleza, netamente medieval en el caso castellano. ${ }^{57}$ No se aparta mucho aquí de tratadistas como Sassoferrato o Diego de Valera. Sin embargo, termina parafraseando de nuevo a Chasseneuz, quien limitaba el poder del rey «en cuanto a la nobleza de sangre y linaje, que esta no se puede quitar». ${ }^{58}$

Enlaza Rades aquí con un planteamiento estamental —inspirado en Mexía y Gratia Dei- ${ }^{59}$ firmemente arraigado en su siglo en el que se «situaba la sangre como valor supremo de la nobleza y como factor de legitimación social». ${ }^{60}$ Uno de los contemporáneos de nuestro autor, Juan García de Saavedra — fiscal de la Chancillería de Valladolid y polemista respecto de la universal hidalguía de los vizcaínos - llegó a afirmar: "Yo soy tan buen hijodalgo como el rey, quia dignitas regiam abundant in nobilitate». ${ }^{61} \mathrm{La}$ cita proviene de alguien que defendía, ante todo, que la nobleza debía estar al servicio del rey, pero ilustra hasta qué punto era importante en el Quinientos la cuestión de la sangre y del linaje. Este argumento era llevado al extremo no mucho después por autores como el bachiller Zaldibia o Arias Villalobos, cuando llegan a defender que la nobleza de los reyes españoles nacía de su carácter de «vizcaínos» originarios. Dicho en palabras de este último poeta:

54. La realidad es que la exención tributaria que se presumía a la nobleza nunca fue completa, no alcanzando generalmente a las alcabalas, al servicio de millones y a otros tributos (véase Carracedo y Abal-Brasón (1989: 516).

55. Pérez (1989: 15).

56. Vigón (1947: 178). Sobre la «inflación nobiliaria» del siglo xvir y las políticas de promoción (y recaudación) de los Austrias menores véase Domínguez Ortiz (1963: 210-213), y Naharro Quirós (1992: 543-544).

57. Las reivindicaciones hidalgas tienen un tímido - aunque muy divulgado- escenario en las cortes castellanas bajomedievales, comenzando por la insegura noticia de las Cortes de Nájera de 1185 (véase Bermejo Cabrero, 2000: 245-249).

58. Catalogus gloriae mundi, c. $8^{\mathrm{a}}$.

59. Se analiza la cuestión en la reciente tesis doctoral de Jiménez Moreno (2011: 106 ss.) Sobre el pensamiento de Mexía véanse, además, Rucquoi (1997) y Heusch (2009).

60. Guillén Berrendero (2009: 94).

61. Tractatus de hispanorum nobilitate et exemptione sive ad Pragmaticam cordubensem quae est 1 . 8 titu. 11, libr. 2 Recopillationis comentarii. Valladolid, 1588, p. 384v; citado por Cárceles de Gea (1989: 72). 
No ay linage en Gracia Dei / de sangre más generosa; / pues es por Lengua y Ley / Cristiana vieja ranciosa / y hidalga más, que el Rey, / que en su antiguo pergamino / vi escripto en Vascuence fino / (si yo por testigo valgo) / que no será el Rey hidalgo I si no fuere Vizcayno. ${ }^{62}$

Aunque el potente argumento tuvo su momento y sus defensores, tuvo también, obviamente, sus detractores. Es el caso de Rades quien, en este breve tratado, defiende que la hidalguía es un privilegio de naturaleza política y, como tal, dimana del linaje o del rey. Se sitúa así en la opinión de autores contemporáneos como Jerónimo Castillo de Bobadilla quien defendía vehementemente que

no dize verdad quien dize: yo soy tan buen hijodalgo como el Rey, al tiempo que pregonaba: la suprema dignidad es del rey Felipe II. ${ }^{63}$

La preeminencia del rey es algo que no niegan las más extremas palabras pronunciadas por un hidalgo, las que concluyen la famosa carta de Lope de Aguirre a Felipe II:

Hijo de fieles vasallos en tierra vascongada, y rebelde hasta la muerte por tu ingratitud. Lope de Aguirre, el Peregrino. ${ }^{64}$

El pensamiento de Aguirre es, si se quiere, más elemental y de clara raigambre medieval, pero comparte con Rades, y en cierta medida también con García de Saavedra, un fondo común que reconoce la autoridad suprema del rey, pero también sus límites. En Rades estos límites se expresan en términos morales en las últimas palabras de su Tratado: el rey puede negar o incluso revocar una hidalguía, pero no puede atentar contra «la nobleza de sangre y linaje, que esta no se puede quitar». En esto, como decíamos, parece coincidir Rades con Mexía, aunque para Guillén Berrendero, en el caso de nuestro autor, «no se trata ya de evidenciar si un individuo ha realizado servicios, sino la antigüedad de los mismos y el "pedigri" de éstos». ${ }^{65}$ Se invierten aparentemente en Rades los términos de la ecuación expresada por mosén Diego de Valera cuando afirmaba que "puede el rey fazer caballero, mas no fijodalgo», ${ }^{66}$ pero en el fondo expresan lo mismo.

62. Extraído de la Alabanza y enchomio de este autor a la primera edición de los Discursos de la antigüedad de la lengua cántabra Bascongada de Baltasar de Echave (México, 1607). La cursiva es nuestra.

63. Jerónimo Castro de Bobadilla, Politica para corregidores y señores de vassallos en tiempo de paz, Madrid: Luis Sánchez, 1597, p. 22.

64. Citado por Arellano (2008: 13).

65. Guillén Berrendero (2009: 278).

66. Citado por Dacosta (2010). 
La nobleza es, ante todo, un ideal, por mucho que se materialice de forma bien heterogénea en el Quinientos. Un estatus objeto de las más aceradas críticas - y clichés - por parte de las mejores plumas del Siglo de Oro, lo que nos habla de su papel protagonista en la vida social del momento. ${ }^{67}$ Un privilegio al que aspiran quienes no lo ostentan, más que una categoría social de perfiles netamente definidos; una frontera social si se quiere, por mucho que tratadistas como Rades trataran de fijar sus contornos. Ni siquiera en los microcosmos urbanos de la España del Quinientos la nobleza tiene contornos perfectamente delimitados, dando cabida a grupos cuasi ennoblecidos como los «cidadãos» de Oporto, los «ciudadanos de inmemorial» de Valencia o los "ciudadanos honrados» de Zaragoza. ${ }^{68}$

Los esfuerzos de juristas como García de Saavedra por fijar la cuestión de la hidalguía desde la teoría y la práctica reflejan un estado de profunda heterogeneidad en el seno de la nobleza, con mayor confusión si cabe en la plástica y multiforme cuestión de la hidalguía. En relación a lo primero, parece clara — desde Domínguez Ortiz - la coexistencia de dos tendencias contrapuestas a finales del siglo xvi: la del cierre de las estructuras — habría que determinar si de forma cíclica o coyuntural-y la de la apertura hacia grupos liminares ${ }^{69}$ Entre estos últimos, los principales - aunque no únicos- serían aquellos que gozan de un éxito social y económico notable, esto es, los burgueses enriquecidos, ${ }^{70}$ emparentados con nobles y participantes en los gobiernos de los grandes concejos de las Coronas de Castilla y Aragón que ven abierto su acceso a la nobleza a través de distintos mecanismos y en distintos momentos de la Edad Moderna. ${ }^{71}$

En este texto Rades recoge algunas de las principales preocupaciones de la tratadística de su momento, pero omite las más importantes desde el punto de vista de sus contemporáneos. Pese a su esfuerzo de definición, ante todo refleja lo que Chauchadis y Laspéras han definido como "l'érosion sémantique et idéologique» de la terminología de la nobleza, reflejo a su vez de la profunda crisis de significación de este estamento. ${ }^{72}$ Creemos que el autor no perseguía sino elaborar un texto de naturaleza histórica, posiblemente un ensayo sobre el

67. «Preciábase un forastero mucho de hidalgo. Y amohinándose un sastre con él, dijo el hidalgo: "¿Vos sabéis qué cosa es hidalgo?». Respondió el sastre: "Ser de cincuenta leguas de aquî"» (Melchor de Santa Cruz, Floresta española, tomo 2, parte V, 141; citado por Chevalier, 2004).

68. Sobre el primer y segundo caso véanse, respectivamente, los trabajos de Ribeiro da Silva (1989) y de Molas Ribalta (1989); para el tercero remitimos a Nicolás (2001).

69. Para lo que aquí tocamos, son aún imprescindibles los trabajos de Domínguez Ortiz (1963) y (1973).

70. Sobre esta cuestión es de referencia el estudio de Molas Ribalta (1985).

71. Se ha señalado la necesidad de establecer un modelo general para las grandes ciudades espańolas del Quinientos como parece permitir el ejemplo conquense (véase Carrasco 1989), no muy diferente del de Burgos (estudiado por Hiltpold 1981). Para el ejemplo de la aspiración nobiliar y del efectivo ennoblecimiento de las élites urbanas valencianas en el siglo XviII, véase Molas Ribalta (1989).

72. Chauchadis y Laspéras (1989: 69). 
origen de la hidalguía castellana, las funciones y obligaciones de la nobleza, y el equilibrio entre merced y privilegio dimanados del soberano. Lo que se conserva de ese presumible plan no resulta especialmente novedoso: Rades y Andrada se limita a expresar de forma personal algunos lugares comunes de la tratadística de su tiempo, con algún resabio crítico contra determinadas «fictiones» (es la bella palabra que emplea) de los nobilistas, y, en cualquier caso, siempre desde la perspectiva y la conciencia del historiador, escrupuloso con la etimología, el buen uso de la lengua y de lo que hoy llamaríamos la terminología, y el conocimiento de primera mano de la documentación.

\section{Apéndice: \\ A. El contexto del tratado}

El ms. 8631, olim X.250, de la Biblioteca Nacional de España es un códice misceláneo del siglo XVII, encuadernado en pergamino, compuesto por 148 fols. en papel de 210x150 mm. Consta de los siguientes elementos:

1) folios 1r-40r: Traslado de una muy solemne proposición que el S. D. Alonso, obispo de Burgos, fizo contra ingleses siendo embaxador en el Concilio de Basilea sobre la preeminencia que el Rey nuestro señor ha sobre el Rey de Inglaterra. La qual, ruego del S. Ioan de Silva, alférez mayor del dicho S. Rey e su compañero en la embaxada, él tornó de latín en romance.

2) fols. 40v-48: [Folios en blanco, con la caja trazada].

3) fols. 49r-52r: Prólogo para haber de tratar de la nobleza y real sangre de el linaje y armas de los Sarmientos y Acunas. ${ }^{73}$

4) fols. 53r-71r : Genealogía de los Sarmientos. ${ }^{74}$

5) fols. 71v-78v: [Folios en blanco, con la caja trazada].

6) fols. 79r-89v: La fundación de los Sarmientos.

7) fol. 90: [Folio en blanco, muy estropeado].

8) fols. 91r-97v: Tratado qué cosa es nobleça, noble, hijodalgo, infançón y cavallero. Por Rades de Andrada, administrador del Sacro Convento de la Calatrava y de la misma Orden.

9) fols. 98r-102v: [Folios en blanco].

10) fols. 103r-129r: Al muy magnifico e poderoso señor e virtuoso, el Marqués de Santillana, Conde del Real, traslado de Angelo, orador italiano milanés.

11) fol. 130r: [Esquema numérico; tal vez un juego]

12) fols. 130v-134v: [Folios en blanco]

13) fols. 135r-148r: Memoria de las personas que han recibido el hábito de

73. Se trata de un texto muy trufado de citas y alusiones, ocasionalmente identificadas en los márgenes. Una valoración de su carácter como leyenda postmedieval acerca de los orígenes de los Sarmiento en Urcelay Gaona (2009: 27-28).

74. Con estructura analística e identificación ocasional de citas en los márgenes del texto. 
la orden y caballería de Calatrava en el sacro convento della desde el año 1535, sacada en suma del libro que está en el dicho convento.

Aunque la mano de este último texto parece la misma que copia el anterior, es claramente distinta de la de los folios del Tratado y de la responsable del texto número 1.

Tal contenido misceláneo parece evidentemente vinculado a, o producto de, dos actividades diferentes, pero que pueden haber sido complementarias: en primer lugar, una indagación sobre la historia de la familia de don Diego Sarmiento de Acuña, quien sería Conde de Gondomar y dedicatario del tratado atribuido a Rades (sería el caso de los miembros 3, 4, 6 del manuscrito); en segundo lugar, una recopilación de textos teóricos relacionados con el tema del tratado (miembros 1, 10). El miembro número 13 podría haber servido tanto a la primera como a la segunda de las actividades mencionadas: la Memoria de las personas que han recibido el hábito... de Calatrava constituye un elemento estrechamente relacionable con la labor de Rades como historiador de esa orden militar, a la que también perteneció don Diego Sarmiento de Acuña. De hecho, podría constituir un material básico para que el propio Rades (o un continuador de su labor) ampliase su Crónica de las tres órdenes publicada en 1572, llevándola hasta una fecha muy posterior a aquella en que el freile concluye su relato, en torno a la época de la anexión del maestrazgo de Calatrava a la Corona (1523). Una conclusión del relato que fue enteramente voluntaria porque si lo prosiguiera — dice Rades— «sería más lisonja de los vivos que historia o memoria de los hechos de aquéllos que ya están libres del vicio de la vanagloria». En efecto, la Memoria de las personas... anota nombres y hechos acaecidos entre $1535 \mathrm{y}$ agosto de 1595, y por consiguiente, desde el punto de vista cronológico, habida cuenta de que Francisco de Rades falleció en 1599, pudo perfectamente haber sido elaborada por él mismo o para él. Sea como fuere, la práctica totalidad de lo reunido en el códice implica una inmersión en fuentes medievales muy congenial con lo que conocemos de las actitudes, actividades y preferencias de Rades como historiador.

Los elementos 1 y 10 son textos de considerable importancia en la historia de la reflexión teórica sobre la nobleza y la caballería en la España de los siglos xv y XVI. El primero es la traducción castellana del famoso discurso pronunciado por Alonso de Cartagena en el Concilio de Basilea el 14 de septiembre de $1434 .{ }^{75}$ Un texto aureolado de prestigio jurídico, como el que alcanzó su autor en la corte de Juan II de Castilla, entre muchas otras cosas como autor del Doctrinal de los caballeros, compilación de leyes que analiza a fondo el título XXI de la segunda Partida

75. Noticia de los manuscritos que han transmitido este texto, buen indicio de su amplia difusión, en Morrás (1991: 224-225). Hay edición del texto latino y de la traducción castellana del discurso de Echevarría Gaztelumendi (1992). 
alfonsí y otros textos de especial relevancia en materia de caballería, como el reglamento de la Orden de la Banda, fundada por Alfonso XI. ${ }^{76}$ El discurso de Basilea muestra a Cartagena como buen conocedor de las obras de Bartolo de Sassoferrato, y, en opinión de Jesús Rodríguez Velasco (1996: 267), es razonable suponer que indujera a Diego de Valera, el más bartolista de los tratadistas castellanos medievales de nobilitate, al estudio detenido de la obra original del jurista italiano. ${ }^{77}$

Por lo que respecta al elemento número 10 del manuscrito, se trata de una copia de la traducción castellana, fechada hacia 1460 y atribuida a un príncipe Carlos de Viana in carcere ${ }^{78}$ del más antiguo tratado sobre la nobleza escrito en el Quattrocento italiano (se trata, en realidad, de un conjunto de dos discursos latinos ambientados en la Roma de la Antigüedad): el De vera nobilitate de Buonaccorso da Montemagno, profesor de derecho en el Studium florentino, colega y protegido de Palla Strozzi. La obra de Buonaccorso, compuesta hacia 1428 ó 1429 como máximo, conoció pronto amplia difusión en Italia y en toda Europa: muy poco después de su redacción, Giovanni Aurispa la tradujo al italiano; en 1449 estaba ultimada la traducción francesa de Jean Mielot (que llegaría a la imprenta en 1478); apoyándose en esta y en el original latino, John Tiptopf realizó su traducción al inglés hacia 1459-1460 (que sería impresa en 1481); de hacia 1470 data la versión alemana de Niclas von Wyle. ${ }^{79}$ Además de la de Giovanni Aurispa, existió otra traducción italiana, realizada por Angelo Decembrio — en todo caso antes de 1454 — para Ínigo López de Mendoza, Marqués de Santillana; de ella derivó la traducción castellana de Carlos de Viana. Hay que subrayar que, en su dedicatoria al Marqués de Santillana, Angelo Decembrio trata de sobreprestigiar la obra atribuyéndosela a Plutarco y reduciendo el papel de Buonaccorso al de traductor latino de un original griego:

la qual obra primeramente fue en lengua griega por el doctísimo autor Plutarco compuesta, e después en latín trasladada por Vonacorso, orador italiano, e finalmente será por mí, Angelo, por el presente y por amor vuestro en toscano transferida. ${ }^{80}$

El manuscrito medieval del que surgió la copia renacentista incluida en el ms. 8631 de la BNE no pudo ser el ms. 17814 (fols. 99r-121v) de la misma

76. Sobre el Doctrinal de los caballeros, véase Fallows (1995).

77. Rodríguez Velasco (1996: 266-267) proporciona un ejemplo luminoso de las muy diferentes apropiaciones y comentarios que de una definición de nobilitas de Bartolo de Sassoferrato hicieron, a pocos años de distancia, Alonso de Cartagena (en el discurso de 1434 al que nos venimos refiriendo), Juan Rodríguez del Padrón en su Cadira de honor (1439) y Diego de Valera en su Espejo de verdadera nobleza (1441).

78. Según Schiff (1905: 115-117). Véase además Cruells (1932).

79. Véase Rabil (1991: 30-31).

80. BNE, MS. 8631, fol. 103r. Bergua Cavero (1995) ha editado y estudiado esta traducción, tomando como base el texto del ms. 17814 de la BNE. 
biblioteca, donde no aparece la dedicatoria de Angelo Decembrio a Santillana (pero sí el epígrafe que insiste en atribuir a Plutarco "la introduçión a la disputaçión de nobleza por él compuesta de Gayo Flaminio e Publio Cornelio Sçipión»). ${ }^{81}$ El antígrafo de la obra de Buonaccorso da Montemagno contenida en el ms. 8631 fue, según Mario Schiff (1905: 115), un códice del siglo xv que perteneció a la Biblioteca Colombina de Sevilla y que a principios del siglo xx pudo ver dicho estudioso en Madrid en poder de Francisco de Uhagón, Marqués de Laurencín (tras la muerte de Uhagón, el códice ha peregrinado por distintas bibliotecas privadas). La importancia del ms. 8631 de la BNE en la transmisión de la traducción castellana del tratado de Buonaccorso es, así, estimable, habida cuenta de que es una copia del manuscrito sevillano llevada a cabo cuando este se encontraba todavía completo (Schiff comprobó que el ms. 8631 contiene 34 líneas finales que, por la pérdida de un folio, faltaban en el códice de Uhagón). En el manuscrito 8631 de la BNE, sin embargo, no se copió un breve y atribulado prólogo de Carlos de Viana, cuyo texto está accesible gracias a Schiff (1905:116-117).

\section{B. Criterios de transcripción}

Desarrollamos las abreviaturas sin indicarlo de ningún modo. Unimos y separamos palabras con arreglo a los usos actuales, excepto en casos como dél, della, desta.

Utilizamos las mayúsculas, puntuamos y acentuamos con arreglo a los criterios de la ortografía de la Real Academia Española vigente.

Mantenemos las oscilaciones en los grupos consonánticos cultos: $c / c c$ (antes de $e, i), m / n m / m m, n / g n, n / n n, s / t, s / b s, t / c t$.Y asimismo las oscilaciones vocálicas (cevil por civil).

Por lo demás, modernizamos las grafías, regularizando las antiguas como $x$ con valor de $/ x /$, alternancias gráficas como $s / s s$ y grafías latinizantes como $p h$ por $f$, carentes de valor fonético. Se regularizan $c, z$ como $c$ ante $e, i$, y como $z$ ante $a, o, u$. E igualmente $q u+a, q u+o$ en $c u+a, c u+o$. Seguimos también la norma ortográfica moderna en los casos de b/v (obejas se transcribe ovejas), $g / j$ (linage se transcribe linaje). Utilizamos $i / j / y$ con valores vocálicos y semivocálicos con arreglo a la norma ortográfica moderna, e igualmente $u / v$. Transcribimos sistemáticamente $m$ antes de $b$ y $p$.

En cuanto a las grafías latinizantes, los grupos $p h$, th, $c h$ se convierten en $f$, $t, c$. Del mismo modo, simplificamos las duplicaciones de consonantes y de vocales hoy inexistentes en español (fee se transcribe fe; illustre como ilustre...); -sc-se transcribe como $c$ en interior de palabra.

Naturalmente, estos criterios no se aplican a las citas de textos medievales (Partidas, Leyes del estilo) incluidas en el texto de Rades.

81. BNE, MS. 17814, fol. 99r. 


\section{El texto}

Tratado qué cosa es nobleza, noble, hijodalgo, infanzón y caballero. Por Rades de Andrada, administrador del Sacro Convento de la Calatrava y de la misma Orden.

Por haberse de tratar en el siguiente capítulo de las libertades que dio el gran Conde don Sancho García, señor de Castilla, a los nobles hijosdalgo della, conviene primero declarar bien qué cosa es nobleza y en qué consiste, y qué es noble, hijodalgo, infanzón y caballero.

Es de saber que estos nombres castellanos, noble y nobleza, vienen de nobilis y nobilitas, diciones latinas, y ellas proceden de un verbo, nosco, que en la voz ativa significa 'conocer', y, en la pasiva, 'ser conocido'. Y su nombre verbal es noscibilis, que quiere decir 'cosa conocible y señalada por alguna calidad buena o mala'. Y por una figura que los latinos llaman síncopa, quitadas del nombre noscibilis tres letras de enmedio, decimos nobilis, y, en castellano, noble. Como estos nombres, fama y famoso, se toman en buena parte y en mala, y decimos "capitán famoso», loándole, y «ladrón famoso», vituperándole, así este nombre noble, en su entera y propia significación, se toma en buena parte y en mala. En buena como decimos «noble caballero», «noble persona»; y en mala, como llamaron «noble ramera» a la isla de Corinto, queriendo decir que fue muy nombrada. También usó de este nombre noble en mala parte San Jerónimo, cuando en una epístola, hablando con Helvidio, hereje y autor de ciertas herejías, dijo estas palabras: "Tú te has hecho noble con tu maldad», ${ }^{82}$ como si dijera: "tú, que no tenías cualidad buena con que fueses conocido y muy nombrado, te has dado a conocer por tus herejías ${ }^{83}$, que te hacen famoso y nombrado, llamándolas por ti helvidianas».

Yo no pretendo escrebir particular tratado de la nobleza, ni hay necesidad dél, pues tenemos muchos en latín y en lengua castellana. Mas para mi historia estoy obligado a dar noticia de la sustancia y ser de la nobleza. Y a vello ${ }^{84}$ con brevedad, aunque no tanta que no pueda parecer prolijidad a los no muy avisados ni agudos de ingenio, que piensan no ser otra cosa nobleza sino hidalguía, al modo y fuero de Castilla, para no contribuir en ciertos tributos y repartimientos reales si no se reparten a exemptos y no exemptos, y para vengar quinientos sueldos y no ser presos por deudas, que todo esto es franqueza y privilegio con presupuesto de hidalguía, como veremos.

Sólo Dios es el que no tuvo principio, y por esto se dice eterno. Mas todos los hombres y las demás criaturas tuvieron prencipio del mismo Dios, su criador. Si Dios, como crió un solo hombre y una sola mujer — que fueron Adán y Eva-, criara dos hombres o más por ventura, los reyes y grandes señores, y los

82. "Nobilis es factus in scelere» (San Jerónimo, De Perpetua Virginitate Beatae Maria. Adversus Helvidium, 16, 224).

83. herejías ] hegias $m s$.

84. vello ] velo $m s$. 
muy aventajados en ingenios, memoria, virtudes morales, hermosura, gentileza, estatura, fuerzas, valentía, discreción o semejantes calidades, lo desvanecieran con una vanagloria. Y quisieran dar a entender que no procedían ellos del tronco y linaje que los pobres hombres y los de poco ingenio, desmemoriados, viciosos, feos, de ruin dispusición, mal proporcionados, de pocas fuerzas, cobardes, necios, y en otras maneras defectuosos. Pues, para que ninguno tenga tan vanos pensamientos, nos trae a la memoria la divina historia del Génesis, y después San Pablo, cómo Dios no crió más de un hombre y una mujer, y dellos descendieron todos los demás por generación en cuanto a los cuerpos y ánimas vegetativas y sensitivas. ${ }^{85} \mathrm{Y}$ en cuanto a las racionales, todas son criadas por el mismo Dios, y juntamente infundidas en los cuerpos humanos. Lo que siempre hizo y hace diferencia estimable de unos hombres a otros es y fue la virtud de algunos y vicio de otros, y así dijo bien un profeta:

Degenerant animi vitiis fiuntque minores,

Exaltat virtus nobilitateque genus. ${ }^{86}$

Dicen estos versos que los hombres viciosos, en cuanto en ellos es, deshonran su linaje, y los virtuosos le ensalzan y ennoblecen, como se dirá bien adelante.

En cuanto a las especies o maneras de nobleza, el famoso y excelente jurisconsulto Bartolo y otros que bien han escrito en esta materia ${ }^{87}$ ponen tres especies de nobleza: una, teologal o sobrenatural, que es estar en gracia y amor de Dios; otra, natural y moral, que es la que procede de las virtudes y hechos conforme a ellas; otra, política o cevil, que se adquiere por diversas vías, como la que llamamos hidalguía.

La nobleza teologal y sobrenatural es la más excelente de todas con incomparable exceso, pues no hay cualidad en el hombre ni la puede haber que se iguale con la excelentísima de estar en gracia y amor de Dios. Lo cual no puede ser sino mediante la fe viva con buenas obras. Mas aquí trataré muy brevemente desta nobleza, porque no podemos saber, si no fuere por divina revelación, cuáles hombres están en gracia y amor con Dios, siendo esto reservado a Su Divina Majestad, que conoce bien los corazones de los hombres y las intenciones buenas o malas con que se hacen las obras exteriores. Los hombres no podemos juzgar sino a tiento, rigiéndonos por las obras en sí buenas que vemos hacer a muchos cristianos, en las cuales puede haber engaño. Pues, como cada día se descubre, algunos

85. Con esa mención génerica alude respectivamente a Génesis, 1 y 2, y a I Ad Corinthios, 15, 45-50.

86. Véase arriba, n. 22.

87. Hay una nota al margen: in.l.ic. De dignitat. L. i.e. 12. Se refiere al tratado De dignitatibus, de Bartolo de Sassoferrato. 
las hacen por vanagloria y muy terrena pretensión de que los otros los tengan en opinión de varones santos y perfectos y los estimen y respecten. De los cuales dijo Nuestro Señor que ya recibieron el premio consiguiendo esta vil pretensión. ${ }^{88}$ En todos tiempos, y en el nuestro tanto como en otros, se han descubierto grandes engaños en esta materia. Y no solo hipocresías en las obras, aviso y palabras, habiendo lobos convertidos de ovejas, mas artificiosos engaños y fictiones de milagros que han querido mostrar y puéstolo por obra algunas personas y engañado con esto mucha gente. De los bienaventurados que gozan de la gloria eterna en el cielo podemos seguramente decir: ganaron en esta vida, mediante la divina gracia, con la fe viva y esperanza y caridad, la nobleza sobrenatural en esta vida, y en ella murieron. Y así en la vida les hacemos veneración. Porque, como dijo el pío profeta y rey David, los amigos de Dios son y merecen ser honrados mucho. ${ }^{89}$ Así, en testimonio desta excelentísima nobleza, los fieles hacemos veneración y reverencia a los santos con ceremonias que no se pueden hacer a emperadores y reyes vivientes, y a los que no sabemos si sus ánimas se salvaron. Si pudiésemos saber con seguridad y sin duda que un pobre pastor o persona más baja está en gracia y amor de Dios en esta vida, habíamosle de dar más honor durante aquel estado que a los puestos en cargos y oficios muy preeminentes, y tenerla por noble de la mejor nobleza de todas. Esta nobleza sobrenatural no la tienen los moros, judíos, herejes ni los cristianos que están en pecado mortal durante aquel estado, por más que sean reyes, prelados o grandes señores.

Nobleza natural no es, como algunos piensan, la heredada de padre y abuelo que llamamos hidalguía, o adquirida por merced o privilegio. Mas es aquella que mana y procede de las obras hechas conforme a las virtudes morales: prudencia, justicia, temperancia y fortaleza, y otras que se llaman partes destas, todas ellas muy naturales al hombre según la naturaleza humana entera y sana, cual fue en los primeros padres, Adán y Eva, antes que pecasen. Esta es la propia naturaleza humana, que la estragada y maculada con el pecado impropiamente lo es, como lo advierten San Agustín y otros santos. ${ }^{90}$ Antes vemos que esta es inclinada a vicios y concupiscencias desordenadas más que a las virtudes, como lo dijo Dios en el Génesis. Después del pecado de Adán tuvo principio en sus hijos la diferencia entre unos hombres y otros, siendo Abel justo y fiel, con obras me-

88. Alude a: «Cum ergo facies eleemosynam, noli tuba canere ante te, sicut hypocritae faciunt in synagogis et in vicis, ut honorificentur ab hominibus. Amen dico vobis: Receperunt mercedem suam» (Mateo, 6, 2).

89. En el margen: Psalmo.1.38. Suponemos que se refiere genéricamente al contenido de dicho salmo, no a un versículo concreto, pues el mismo no tiene más de 6 .

90. Al margen: De libero arbi., cap. 19. Alude a este pasaje: «Sic etiam ipsam naturam aliter dicimus, cum proprie loquimur, naturam hominis, in qua primum in suo genere inculpabilis factus est: aliter istam, in qua ex illius damnati poena, et mortales et ignari et carni subditi nascimur; iuxta quem modum dicit Apostolus, Fuimus enim et nos naturaliter filii irae, sicut et caeteri» (San Agustín, De libero arbitrio, III, 19). 
ritorias, y Caín, su hermano, muy perverso y obstinado en malas costumbres. Tanto que, por invidia de que Dios aceptaba los sacrificios de Abel su hermano y no solos los suyos, le quitó la vida. No dejó Abel generación, mas sucediole en la nobleza natural su hermano Set, que fue caudillo de virtuosos como lo fue Caín de malos y perversos. Y así San Agustín llama ciudad de Dios a Set y sus descendientes, los que siguieron sus pisadas, y ciudad del demonio a Caín y a los de su bando. ${ }^{91}$ De aquí entenderá cualquier hombre discreto y amigo de saber apuradas verdades: que, como arriba decía, el prencipio de la verdadera nobleza natural fue la virtud manifestada con obras conformes a ella regladas por la ley natural; y el de la bajeza y vileza fue el mal uso de la ley natural y libre albedrío. Por esto en la divina historia del Génesis los virtuosos son llamados hijos de Dios, y los viciosos hijos de los hombres, dando a entender que los unos parecían más que hombres, regulando sus obras, palabras y pensamientos conforme a la ley natural, centella y rayo de la divina eterna, y los otros no tratan sino de vivir como animales, conforme a sus apetitos desordenados y ajenos de la razón y ley natural. Los hombres doctos y discretos que muy de raíz entienden esta materia dicen que nobleza natural, propia y verdaderamente, es una excelencia y buena cualidad emanada de alguna virtud en el hombre que llevó de sus obras, reguladas y niveladas por ella.

Preguntado Demócrito, filósofo gentil, en qué consiste la verdadera nobleza natural, respondió: la de los animales brutos consiste en cosas del cuerpo, mas la de los hombres en las buenas costumbres. Dijo muy bien, porque si por las victorias contra nuestros enemigos - el demonio y el mundo y nuestra propia sensualidad - son una muy recia y peligrosa pelea, bien lo entendió Platón, filósofo sapientísimo aunque gentil, cuando en su libro de las leyes dijo que la primera y más esclarecida victoria que un hombre puede alcanzar es vencerse a sí mismo. ${ }^{92} Y$ por el contrario, dejarse vencer de los vicios y desordenados apetitos es la mayor bajeza y villanía en que puede caer. No menos dice una ley destos reinos hecha por los más discretos y sabios que había en Europa por orden y comisión del rey don Alonso el Sabio, y es la sexta del título nono de la Partida segunda, cuyas palabras son las siguientes: «nobles son llamados en dos maneras, o por linaje o por bondad. E comoquiera que el linaje es nobleza, la bondad pasa e vence la nobleza», que esta ley llama de bondad a la adquirida por obras de virtud, y está en un capitulo del Decreto: se llama nobleza de costumbres. Y en otro de las Decretales, nobleza de virtudes.

Nobleza política o cevil es aquella que se adquiere por herencia de padre y abuelo en cuanto a las preeminencias y libertades. $\mathrm{O}$ por estudios y grados en buenas ciencias. $\mathrm{O}$ por títulos y dignidades de emperadores, reyes, príncipes, duques, ricos hombres, condes, marqueses, barones, almirantes y otros que hay

91. Alude a San Agustín, De civitate Dei, XV, particularmente, caps. 1-8.

92. Recuerda Platón, Leyes, I, 626e. 
en cada tierra. $\mathrm{O}$ por servicios muy notables hechos a emperadores, reyes y otros príncipes que pueden dar nobleza cevil y política. O por otra justa causa que la den, de muchas que puso Casaneo en su Catálogo de la gloria del mundo, en la consideración octava, lo que dicen letrados que los reyes pueden dar hidalguía con franquezas anejas a ella por sus leyes, mas verdadera nobleza no la pueden dar: hase de entender de la natural que consiste en obras virtuosas y de la que de alguna manera se hereda de las virtudes y grandes hechos de sus progenitores. Mas la pura civil y política, que es la tercera y más ínfima especie de nobleza de todas las tres arriba declaradas, muy bien la pueden dar los reyes por alguna de las causas ya dichas o sus semejantes, en cuanto a que un hombre, no siendo antes hijodalgo de sangre o linaje, lo sea por merced del rey, y goce de las mismas libertades y preeminencias que los hijosdalgo de sangre en todo lo que no fuere contra leyes o estatutos que tengan confirmación real. Y sus descendientes serán nobles desta nobleza si la merced no fuese mirada a cierto grado.

De lo dicho se colige que la nobleza heredada y llamada hidalguía, en un hombre vicioso y de malas costumbres no es natural ni propia, sino solamente una calidad para gozar de franqueza y libertades en razón de haberlas gozado su padre y su abuelo por la fama y opinión de que las gozaron otros progenitores suyos. Estos, aunque para los tales efectos sean preferidos a los que no son hijosdalgo de sangre o no lo pueden probar, en realidad de verdad no igualan a los nobles de nobleza natural que nace de la vida virtuosa, y consiste en el ánimo valeroso para vencer sus apetitos sensuales. Dice el sabio Boecio, en el libro tercero De consolación, que la nobleza heredada de los padres y progenitores hace claros a ellos y no a los hijos y decendientes, que a ellos sólo su propia virtud puede les puede dar verdadera nobleza. Así dice Ovidio:

Nam genus et proavos et, quae non fecimus ipsi vix ea nostra voco. ${ }^{93}$

Quiere decir: el linaje y abolengo noble y lo demás que no procede de obra propia nuestra apenas se puede llamar cosa nuestra. El poeta Juvenal, con lindos términos, hace burla de un romano que, siendo vicioso y preciándose de la nobleza de sus progenitores sin ser imitador de sus hazañas y buenas obras, tenía las paredes de su casa llenas d'escudos de armas, banderas y retractos de sus pasados y pinturas de sus victorias y trofeos, gastando él días y noches en juegos y regalos y otros vicios que con estos andan. $\mathrm{Y}$ al fin concluye diciendo lo siguiente:

Tota licet veteres exornent undique cerae atria: nobilitas sola est atque unica virtus. ${ }^{94}$

93. Al margen: Metamor. 13. Se trata de Ovidio, Metamorfosis, XIII, 140-141.

94. Al margen: Satira 8. Se trata de Juvenal, Sátiras, VIII, 19-20. 
Quiere decir: «por más retratos que tengas de tus progenitores en tus salas, yo te hago saber que solamente la virtud es la verdadera y única nobleza». Grande número de autoridades de hombres muy sabios, cristianos y gentiles, pudiera yo traer en confirmación desta verdad. Mas para los discretos basta lo dicho: el que junto con la nobleza de linaje tiene la natural y verdadera, nacida de obras virtuosas y virtuosamente hechas, propias suyas, tiene una buena calidad que es la nobleza cevil y política sobre otra mejor que es la natural, como dice bien la ley de la Partida que tengo alegada. Y este tal con razón se puede preciar cristianamente de noble, referiendo lo uno y lo otro a Dios, que le dio tales calidades, y no desvaneciéndose como Lucifer.

En cuanto al nombre fidalgo, hijodalgo, hidalgo, yo me atengo a la denominación que le dieron los doctísimos juristas que ordenaron las leyes de las Partidas, en una de las cuales (que es la segunda del título veinte y uno, en la Partida segunda), donde tratando cómo han de ser escogidos los milites o caballeros para la guerra, dicen estas palabras, después de haber dicho las calidades que para esto miraban los sabios antiguos y son formales en aquel antiguo linaje: ${ }^{95}$

Ca mucho tuvieron que era mejor el home flaco e sofridor qu.el fuerte ligero para fuir, e por esto sobre todas las cossas cataron que fuesen homes de buen linage, porque se guardasen de façer cossa por que podiesen caher en vergüença. E porqu estos fueron escogidos de buenos logares, e con algo, que quiere tanto dezir en lenguage d'España como 'bien', por esos los llamaron fixosdalgo, que muestra tanto como fixos de bien. En algunos otros logares los llamaron gentiles, e tomaron este nombre de gentileça, que muestra tanto como nobleça de bondad, porque los gentiles fueron homes nobles e buenos e vivieron más ordenadamente que las otras gentes. Esta gentileça avían en tres maneras: la una por linage, la otra por saver, la terçera por bondad de costumbres o de maneras. E como quiera questos que lo ganan por sabiduría e por su bondad son por derecho llamados nobles e gentiles, mayormente lo son aquellos que loan por linage antiguamente, e façen buena vida, porque les viene de lueñe como heredad.

Todo esto dice aquella ley fundada en razón natural. Gregorio López, licenciado y uno de los del Real Consejo de las Indias, en la glosa sobre esta ley en cuanto a la denominación deste nombre de hidalgo ${ }_{2}$ fue de otra opinión, pareciéndole más a propósito que se diga hidalgo y venga de este nombre latino itálico, y otro tiempo se llamasen itálicos los que por privilegios gozaban de las franquezas y preeminencias de los italianos, que eran grandes en tiempo de los emperadores romanos gentiles y cristianos antiguos, y de itálicos viniesen a decir los españoles hidalgos. Esta opinión mantuvieron también el licenciado Juan Arce de Otálora, en su Tratado de nobleza, y el doctor Ginés de Sepúlveda, en una de sus epístolas. Mas nunca me pareció bien, y menos después que he visto grande número de

95. en el margen, corregido: lenguaje. 
antiguas escrituras donde se halla este nombre - fidalgo y fixodalgo-, con esta letra $F$, y en otras menos antiguas hidalgo y hijodalgo, con $H$ al principio, y en ninguna he leído idalgo para que se pudiese sospechar que se corrompió el nombre de itálico en idalgo. No hace en favor desta nueva opinión la ley primera del título De cinsibus, en los Digestos, que declara gozar del privilegio y derecho de los italianos los pacenses y emeritenses en Lusitania, provincia de España, que eran los de Beja ${ }^{96}$ y Mérida, porque la causa dello era ser estas ciudades colonias de romanos. Después, el emperador Flavio Vespasiano dio previlegio a todos los españoles de gozar de los honores, franquezas y preeminencias de que gozaban los pueblos latinos, comarcanos a Roma, que casi fue hacerlos ciudadanos romanos en cuanto a esto, cosa la más estimada en aquellos tiempos en materia de honores y libertades. De manera que, si por el previlegio de Italia o de los pueblos latinos se hubieran llamado itálicos y después idalgos los nobles de linaje en España, todos los españoles habían de ser nobles de linaje o hidalgos, pues a todos se dio aquel previlegio, como lo escribió Plinio en su Natural historia, y después otros buenos historiadores que siguió Ambrosio de Morales en su Crónica. ${ }^{97}$ Por tanto, me parece más cierta la opinión —o por mejor decir, declaración — de la ley de la Partida, que como algo quiere decir 'bien', así hijodalgo (abreviando el nombre, hidalgo), quiere decir 'hijo de bien', que es hijo de hombre de calidad y señalado en estado, señorío, solar antiguo y honroso, haciendas y riquezas bien adquiridas por las armas o por letras, o por grandes servicios hechos al rey o a su patria, o por otras honrosas vías. Que la hacienda y bienes temporales se llame en antiguo castellano algo pruébalo también otra ley que es la segunda, del título veinte y uno en la Partida primera, y dice así: «algo, aviendo los clérigos de qualquier manera que lo ganen derechamente, es llamado pegujan». Colígese de lo dicho que, si en realidad de verdad un hombre no es noble o hijodalgo de linaje, no lo será aunque con grande número de testigos pruebe falsamente que su padre y abuelo fueron nobles o hijosdalgo, y por esto no pecharon y tuvieron varas de justicia y regimientos en el partido de los hijosdalgo. Y aunque en razón desta probanza y sentencia con ejecutoria por ella dada se le guardaran las preminencias como si realmente fuera hijodalgo, no lo será por ella en realidad de verdad. Por el contrario, si un hombre es realmente noble o hidalgo de linaje y le empadronan para que peche, y por falta de testigos verdaderos y sobra de falsos, o por no seguir la causa - como hacen los muy pobres y de poco ánimo- se da sentencia contra él que sea pechero, o sin ella le hacen pechar, no por eso dejará de ser noble o hijodalgo, aunque perderá las preeminencias de la hidalguía, por cuanto los alcaldes en el fuero judi-

96. Beja ] Boja en el ms. Suponemos que se refiere a la ciudad portuguesa, llamada por los romanos Pax Iulia o Civitas pacensis, de donde deriva el gentilicio pacense. Este gentilicio ha sido tradicionalmente aplicado en España a los naturales de Badajoz, ciudad fundada en realidad por los árabes en el s. IX.

97. En el margen: lib. 46, 3.c.3. 
cial no juzgan ni pueden juzgar sino según lo alegado y probado. Cada día vemos que dos hermanos hijos de unos mismos padre y madre, siendo empadronados en diversos concejos, el uno probó su hidalguía y sacó ejecutoria, y el otro no la pudo probar. Y, en cuanto a la verdad, si el uno es hijodalgo, también lo es el otro, en cuanto son hijos de un padre y una madre, que otra cosa sería si el uno tuviese privilegio real de hidalguía y el otro no.

En las probanzas de hidalguías se acostumbra articular que «es hijodalgo de solar conocido y de vengar quinientos sueldos», y los receptores preguntan a los testigos estos dos puntos, que muy pocos entienden para poder responder a ellos. Porque cuál sea solar conocido es dificultoso de saber, y qué derecho sea el de vengar quinientos sueldos no lo saben aun algunos de los letrados, por guiarse muchas veces por malas historias y dichos vulgares, teniendo leyes destos reinos que lo declaran. Una de las falsas opiniones que yo hallo es que el vengar quinientos sueldos tuvo prencipio de haber repartido el rey don Alonso el de las Navas ${ }^{98}$ a cada hijo cinco maravedís de tributo que, si como algunos dicen eran de oro, no era poco para en aquellos tiempos. Y haberse juntado ellos en la glera de Burgos y llevado cada uno cinco maravedís en la punta de su lanza atados en un paño y enviado a decir al rey fuesen sus receptores a cobrar aquel nuevo tributo, dando a entender que no lo pagarían, y así no paso adelante. No menos fabuloso es decir que, habiendo cargado el rey Mauregato de León aquel desonesto tributo de dar cada año a los moros cien doncellas, se concertó el rey don Bermudo su subcesor en dar quinientos sueldos de cada doncella, y esto quitó el rey don Ramiro habiendo vencido a los moros en el Clavijo, y los hijosdalgo que con él se hallaron se preciaron de haber vengado aquellos quinientos sueldos. Pues vayan estas fabulosas opiniones y otras tales para varias fictiones, y hablen las leyes destos reinos diciendo como dicen que hidalgo de vengar quinientos sueldos quiere decir 'hidalgo que por la injuria y daño que en su persona o en su honra o hacienda le fue hecho podía vindicar y recebir de su adversario en satisfación dello quinientos sueldos, moneda de aquellos tiempos, y el no hijodalgo solamente trecientos'. En el Fuero castellano, en la ley veinte y nueve dice:

«y este que es así prendado sobre esta prenda hiciere fuero y derecho a este que le prendó, después puede le demandar quinientos sueldos porque lo deshonró, tomando la prenda de su cuerpo».

La ley setenta y una dice: «si algún fidalgo deshonrare a otro, si quisiere el deshonrado debe recebir emienda de quinientos sueldos, e si no quisiere, puédele desafiar y matar por ello si quisiere». Adelante, la ley setenta y tres dice: «en estos denuestos y cada uno dellos, si es fidalgo, quinientos sueldos; y si es labrador, trecientos sueldos». El rey don Alonso, último deste nombre, en las cortes

98. de las Navas] denas Navas ms. 
que celebró en Alcalá de Henares, hizo una ley que está en el libro cuarto de las Ordenanzas reales y es la oncena del título once, la cual dice así:

Ningún fijodalgo ni otro hombre no tome por fuerça de lo solariego, ni de lo abadengo, ni de realengo, ni de la behetría, ni de otro hombre ninguno, porque no ay razón por que lo tomar. E si lo tomare, aquel día mesmo lo deve pagar: pan, vino, y paja, y çevada, y leńa, y ortaliça. Y esto si le tomare (buey, o vaca, o carnero, o obeja, o puerco, o cabra, o cabrón, o lechón, o cordero, o ansarón, o gallina, o capón), débelo pechar luego doblado: por uno, dos de aquella natura e de aquella edad. Y de cada solar en que tomaren, débele pechar treçientos sueldos que montan desta moneda docientos y cuarenta maravedís, si fuere do lo tomare de labradores. E si fuere de fijosdalgo, quinientos sueldos que montan desta moneda quatroçientos maravedís. Y lo otro al rey, así como a aquel que toma lo ageno por fuerça.

Entre las Leyes del estilo hay una, que es la ochenta y cinco, y dice así:

Otrosí es de saber qu.el hijodalgo no será así juzgado como otro que no es hijodalgo. Y la pena de la deshonra del hijodalgo es quinientos sueldos. E si qualquier otro que no sea hijodalgo demanda pena de deshonra, si por fuero hay pena, esa juzgarán. E si no, juzgarán la pena de cuantía de quinientos sueldos ayuso, porque no ha de haber tan gran cuantía como el hijodalgo.

Claro es por lo dicho que, cuando se dice "vengar quinientos sueldos», este verbo vengar no viene de vindico, que es 'tomar venganza', como muchos lo han entendido mal, sino de bendico, que quiere decir 'apropiar y pedir por suya una cosa'. Con eso, no es menester añadir una silaba y decir «hidalgo de devengar quinientos sueldos», como algunos quisieron decir.

Infanzón, en lenguaje antiguo castellano, es lo mismo que 'hijodalgo sin título ni estado'. Y aunque ya no se usa en Castilla este nombre, úsase en Aragón. Finalmente, para fin de la materia de nobleza, conviene aquí dar aviso a los que no lo saben que hay grande diferencia entre hidalgo y noble, porque para ser hidalgo basta ser hijo y nieto de hidalgo, aunque la madre y abuela no lo fuesen, y para ser noble requiérese hidalguía de padre y madre. Estos dos pone expresamente la ley tercera del título veinte y uno en la Partida segunda por estas palabras: «maguer la madre sea villana, e el padre hidalgo, hijodalgo es el fijo que dellos nasciere; e por hijodalgo se puede contar, mas non por noble».

Caballero en castellano quiere decir propiamente 'hombre noble o hijodalgo armado caballero por algún rey o en alguna orden de las militares como son las de Santiago, Calatrava, Alcántara y San Juan y otras semejantes'. Mas en ordinario lenguaje llaman caballeros a los duques, condes, marqueses y otros señores de vasallos o mayorazgos principales, aunque ni tengan hábito militar ni sean armados caballeros al uso antiguo. Dice la ley once del título veinte y uno en la Partida segunda que los emperadores y reyes no deben ser consagrados ni coronados hasta ser armados caballeros, y las solenidades con que se solían armar ponen las leyes trece y catorce del mismo título, que son bien de notar, aunque lo más substancial 
se hace en las órdenes militares cada día. Está ya tan estragado todo esto en el vulgar lenguaje que llaman caballeros a hombres muy ajenos destas calidades por tener buena renta y criados y caballos, y aun estos tales, más atrevidamente que los muy nobles, juran a fe de caballero. Pero dejémoslos con el pago que les dan algunos de los que oyen tal juramento y los conocen muy bien.

\section{La franqueza y libertades que dio el gran conde don Sancho a los hijosdalgo de Castilla para no pagar pechos ni ir a la guerra sin sueldo}

Siempre se va manifestando que no consiste la hidalguía y nobleza en no pagar a rey ni a otro señor los tributos que llaman pechos. Y aquí se comprobará bien. Dice el arzobispo don Rodrigo que los hijosdalgo y caballeros, a los cuales en latín llama milites castellanos, hasta el tiempo del conde don Sancho, señor de Castilla, pagaban tributos y eran obligados a servir al señor desta tierra en las guerras sin sueldo. $\mathrm{Y}$ este buen conde les dio franqueza y privilegio de no pagar tributo ni servir sin sueldo. ${ }^{99} \mathrm{La}$ Corónica general dice lo mismo, y declara que los tributos que antes pagaban eran los que llaman pechos porque dice así:

E dio libertad e franqueça a los cavalleros castellanos que non pechassen ni fuesen en veste sin soldadas desús, ca antes desto pechaban, aunque avían de ir con el señor sin soldadas.

Los historiadores menos antiguos, en lugar del nombre latino milites que puso el arzobispo y del nombre caballero, que vemos en la general, usan deste nombre: hijosdalgo. $\mathrm{Y}$ es cierto que dio el conde aquel previlegio no solamente a los caballeros que entonces eran los armados con las solenidades acostumbradas, mas a todos los nobles y hijosdalgo de todo su señorío. Y pues todos ellos eran pecheros antes deste previlegio y franqueza dada por el conde don Sancho, claro está que la nobleza, hidalguía y caballería no consiste en en no pechar, aunque esta es una de sus preeminencias después de aquel previlegio. Otras tenían por las que les eran diferenciados de los villanos, mas, en cuanto a pechar, todos eran iguales. Así vemos que en el Andalucía pechan los hijosdalgo y caballeros, y por el contrario, en algunos lugares destos reinos no pechan hijosdalgo ni labradores por tener previlegio el mismo lugar para sus vecinos, como lo tienen otros para que los hidalgos pechen por la hacienda que allí poseen. También se entenderá que cuando un rey, por pragmática o en otra manera, dispone y ordena que los hijosdalgo, si no tuvieren armas y caballo, o si tuvieren algún oficio vil, no gocen de la hidalguía, ha lugar en cuanto a la franqueza que tenían de no pechar y otras preeminencias dadas por leyes y mandas o privilegios, y no en cuanto a la nobleza de sangre y linaje, que esta no se puede quitar.

Para don Diego Sarmiento de Acuña.

99. Remite a Rodrigo Ximénez de Rada, Historia de rebus Hispaniae, V, III. 


\section{Bibliografía}

Acquier, Marie Laurie. «Los tratados en prosa e Antonio López de Vega: aproximación al discurso político en el siglo XvII", Cuadernos de Historia Moderna, 24 (2000), pp. 85-106.

Andanças e viajes de un hidalgo español Pero Tafur (1436-1439), Estudio y descripción de Roma, por José Vives Gatell, y presentación, edición, ilustraciones y notas por Marcos Jiménez de la Espada. Con una presentación bibliográfica de Francisco López Estrada e indices onomástico, toponimico y de materias por Carmen Sáez, Rafael Morales y Juan Luis Rodríguez, Barcelona, El Albir, 1982.

Antonio, Nicolás, Bibliotheca Hispana Nova, sive Hispanorum scriptorum qui ab anno MD, ad MDCLXXXIV floruere notitia....Tomus primus, Madrid, Joaquín de Ibarra, 1783.

Arce de Otálora, Andrés, Summa nobilitatis hispanicae, Salamanca, Andrea de Portonariis, 1559.

Arellano, Ignacio, «Rebeldes y aventureros del Siglo de Oro en sus autobiografías», en Hugo R. CoRtés y Eduardo Godoy; Mariela Insúa (eds), Rebeldes $y$ aventureros: del Viejo al Nuevo Mundo, Madrid, Iberoamericana/Vervuert, 2008, p. XXX-XXX.

Bergua Cavero, Jorge, "El Príncipe de Viana y su traducción pseudoplutarquea», en Estudios sobre la tradición de Plutarco en España (siglos XIII-XVII), Zaragoza, Departamento de Ciencias de la Antigüedad-Universidad de Zaragoza, 1995, pp. 95-135.

Bermejo Cabrero, José Luis, "En torno a las Cortes de Nájera», Anuario de Historia del Derecho Español, 70 (2000), p. 245-249

CárCeles de Gea, Beatriz, «Nobleza, hidalguía y servicios en el siglo Xvil castellano", en Hidalgos et hidalguia dans l'Espagne des XVI et XVII siécles, Théories, pratiques et représentations, París, CNRS, 1989, pp. 71-93.

Carceller Cerviño, Ma del Pilar, Realidad y representación de la nobleza castellana del siglo XV: el linaje de la Cueva y la casa ducal de Alburquerque, Tesis doctoral, Madrid, Universidad Complutense, 2006.

CARlé, María del Carmen, "Infanzones e hidalgos», Cuadernos de Historia de España, 33-34 (1961), pp. 56-100.

Caro Baroja, Julio, Las falsificaciones de la Historia (en relación con la de España), Barcelona, Seix Barral, 1992.

Carracedo, Carmen y Abal-Brasón, Manuel de, «Una exención tributaria medieval en el marco del derecho nobiliario castellano», Anuario de Historia del Derecho Español. 59 (1989), pp. 493-494.

Carrasco, Raphaël, "Les hidalgos de Cuenca à l'époque moderne», En Hidalgos et hidalguía dans l'Espagne des XVI et XVIT siécles. Théories, pratiques et réprésentations, París, CNRS, 1989, pp. 167-188.

Carrasco Martínez, Adolfo, «La aristocracia en la Europa dividida. La idea de 
nobleza en la Europa de la segunda mitad del siglo XVI», en Gregorio DEL Ser Quijano (coord), Congreso V Centenario del Nacimiento del III Duque de Alba, Fernando Álvarez de Toledo. Actas: Piedrahita, El Barco de Ávila y Alba de Tormes (22 a 26 de octubre de 2007), Salamanca, Universidad, 2008, pp. 653-662.

—, «Herencia y virtud. Interpretaciones e imágenes de lo nobiliario en la segunda mitad del siglo XVI», En Ribot, L. y Berenguer, E. (coords), Las sociedades ibéricas y el mar a finales del siglo XVI, Tomo IV. La Corona de Castilla, Madrid, Sociedad Estatal Lisboa’98, 1998, pp. 231-271.

—, "La formación de los valores nobiliarios en el reinado de Isabel la Católica», Cuadernos de Investigación Histórica, 21 (2004), pp. 21-37.

Carrasco Martínez, Adolfo, Martín Barriguete, Fermín, Martínez Vega, María Elisa, Privilegio y desigualdad. Perspectivas de estudio en Historia social de la España moderna, Madrid, Universidad Complutense, 2004.

Castillo de Bobadilla, Jerónimo, Politica para corregidores y señores de vassallos en tiempo de paz, Madrid, Luis Sánchez, 1597.

CavaIllac, Michel, "L'hidalgo-mercader dans la littérature du Siècle d'Or», en Hidalgos et hidalguía dans l'Espagne des XVI et XVII siècles. Théories, pratiques et représentations, París, CNRS, 1989, p. 105-124.

Chasseneuz, Barthélemy de, Catalogus gloriae mundi Bartholomei Cassanaei Burgundi, Francfort, Segismundus Feyerabend, 1579.

Chauchadis, Claude, y Jean Michel Laspéras, "L’hidalguía au XVI e siècle: coherence et ambiguités", en Hidalgos et hidalguía dans l'Espagne des XVI et XVIT siècles. Théories, pratiques et représentations, París, CNRS, 1989, pp. 47-70.

Chevalier, Maxime, "Cuentecillos y chistes tradicionales en la obra de Quevedo", en Las sátiras de Quevedo y su recepción. Antología crítica, Lía Schwarz (comp), Madrid: Centro Virtual Cervantes, 2004. Consultado el 15/06/2012. URL: http://cvc.cervantes.es/obref/quevedo_critica/satiras/ indice.htm

Conde y Delgado de Molina, Rafael, «La salva de la infanzonía aragonesa: fueros, praxis documental y archivo", Aragón en la Edad Media, 14-15 (1999), pp. 313-328.

Covarrubias, Sebastián de, Tesoro de la lengua castellana o española, Madrid, Turner, 1977.

Cruells, Manuel, «Alguns documents sobre la vida cultural i literària de Carles de Viana», Estudis Universitaris Catalans, XVII (1932), pp. 86-94.

Dacosta, Arsenio, "De la conciencia del linaje a la defensa estamental. Acerca de algunas narrativas nobiliarias vascas», Medievalista, 8 (2010). Consultado el 30/05/2012. URL: http://www2.fcsh.unl.pt/iem/medievalista/

Díaz de Durana, Ramón, La otra nobleza. Escuderos e hidalgos sin nombre y sin historia. Hidalgos e hidalguía universal en el País Vasco al final de la Edad Media (1250-1525), Bilbao, Universidad del País Vasco, 2004, pp. 228-264.

Díaz de Durana, José Ramón, y Alfonso de Otazu, «L'autre noblesse. 
L'hidalguía universelle au Pays Basque à la fin du Moyen Âge», Histoire \& Sociétés Rurales, 35 (2011), pp. 61-62.

Domínguez Ortiz, Antonio, La sociedad española en el siglo XVII, I. El estamento nobiliario, Madrid, CSIC, 1963.

—, Las clases privilegiadas en el Antiguo Régimen, Madrid, Istmo, 1973.

Echevarría Gaztelumendi, María Victoria, Edición crítica del discurso de Alfonso de Cartagena "Propositio super altercatione praeminentia sedium inter oratores regum Castellae et Angliae in Concilio basiliense»: versiones en latín y castellano, Madrid, Universidad Complutense, 1992.

Egido, Aurora, «La Nobleza virtuosa de la Condesa de Aranda, doña Luisa de Padilla, amiga de Gracián», Archivo de filología aragonesa, 54-55 (1998), pp. 9-41.

Elliot van Liere, Katherine, «Humanism and Scholasticism in Sixteenth-Century Academe: Five Student Orations from the University of Salamanca», Renaissance Quarterly, 53-1 (2000), pp. 57-107.

Fallows, Noel, The Chivalric Vision of Alfonso de Cartagena: Study and Edition of the Doctrinal de cavalleros, Newark, Delaware, Juan de la Cuesta, 1995.

Fechner, Jörg-Ulrich, «Anton Schneeberger (1530-1581). Zur Erinnerung an einen deutsch-polnischen Mittler, aus Anla $\beta$ eines Buches aus seiner Bibliothek», En Daß eine Nation die ander verstehen möge: Festschrift fur Marian Szyrocki zu seinem 60. Geburtstag, eds. Roloff, Hans-Gert, HonszA, Norbert, Amsterdam, Rodopi, 1988.

Fernández Albadalejo, Pablo y Portillo Valdés, José Manuel, «Hidalguía, fueros y constitución política: el caso de Guipúzcoa», en Hidalgos et hidalguía dans l'Espagne des XVI et XVII siècles, Théories, pratiques et représentations, París, CNRS, 1989, pp. 149-165.

Fernández IzQuierdo, Francisco, «Honor y prestigio por la gracia del rey de España: Los caballeros de hábito militar en el inicio del reinado del tercer Felipe», En Sanz Camañes, Porfirio (coord), La monarquía hispánica en tiempos del Quijote, Madrid, 2005, pp. 189-230.

FINZI, Claudio, «La polemica sulla nobiltà nell'Italia del Quattrocento», Cuadernos de Filología Clásica. Estudios Latinos, 2010, 30(2), pp. 341-380.

García de SaAvedra, Juan, Tractatus de hispanorum nobilitate et exemptione sive ad Pragmaticam cordubensem quae est 1.8 titu. 11, libr. 2 Recopillationis comentarii, Valladolid, 1588.

García Hernán, David, «El estamento nobiliario: Los estudios clásicos y el nuevo horizonte historiográfico", Hispania, 53 (1993), pp. 497-539.

Gerbet, Marie-Claude, y Janine Fayard, «Fermeture de la noblesse et pureté de sang dans les concejos de Castille au XVème siècle: à travers les procès d'hidalguía", Histoire, économie et société, 1 (1982), pp. 51-75.

Guardiola, Juan Benito, Tratado de nobleza y de los titulos y ditados que oi día tienen los varones claros y grandes de España, Madrid, 1591.

Guillén Berrendero, Juan Antonio, «La tratadística nobiliaria como espejo 
de nobles. El ejemplo de Juan Benito Guardiola y su Tratado de nobleza de 1591», Brocar, 26 (2002), pp. 81-106.

-, "Juan Benito Guardiola. Honor y nobleza en el siglo xvi. Pervivencia y "mudanza" en los valores nobiliarios», Brocar 28 (2004), pp. 117-143.

Guillén Berrendero, José Antonio, La idea de nobleza en Castilla durante el reinado de Felipe II, Valladolid, Universidad de Valladolid, 2007.

-, Los mecanismos del honor y la nobleza en Castilla y Portugal, 1556-1621, tesis doctoral, Madrid, Universidad Complutense, 2009.

Haupt, Paul, «Hidalgo and Filius Hominis», Journal of Biblical Literature, 40, No. 3/4 (1921), pp. 167-168.

Herrera Montero, Bernal, «Fuenteovejuna de Lope de Vega y el maquiavelismo", Criticón, 45 (1989), pp. 131-153.

Heusch, Carlos, «Le chevalier Ferrán Mexía et son Nobiliario vero (1492): de l'imaginaire chevaleresque à la logique de l'exclusion", Atalaya, 11 (2009). Consultado el 01/09/2012. URL: http://atalaya.revues.org/598.

Hiltpold, Paul, «Noble Status and Urban Privilege: Burgos, 1572», The Sixteenth Century Journal, 12, no 4 (1981), pp. 21-44.

Jiménez Moreno, Agustín, Nobleza, guerra y servicio a la Corona: los caballeros de hábito en el siglo XVII, Madrid, Universidad Complutense, 2011.

Kirschner, Teresa J, «La importancia de la tradición oral y el héroe unanimista en Fuenteovejuna de Lope de Vega», En Actas del Sexto Congreso Internacional de Hispanistas, Toronto, University of Toronto, 1980, pp. 419-422.

LaCarra, José María, «En torno a la propagación de la voz hidalgo», En Homenaje a Don Agustín Millares Carlo, Las Palmas, Caja Insular de Ahorros de Gran Canaria, 1975, vol. II, pp. 43-53.

Ladero Quesada, Miguel Ángel, «Una biografía caballeresca del siglo Xv: "La Coronica del yllustre y muy magnífico cauallero don Alonso Pérez de Guzman el Bueno"», En la España Medieval, 22 (1999), pp. 247-283.

Lambert-Gorges, Martine. "Le bréviaire du bon enquêteur, ou trois siècles d'information sur les candidats à l'habit des ordres militaires», Mélanges de la Casa de Velázquez, 18-1 (1982), pp. 165-198;

Lomax, Derek W, «La obra histórica de Rades y Andrada», en Crónica de las tres órdenes de Santiago, Calatrava y Alcántara, Barcelona, El Albir, 1980, pp. v-XI.

López de Vega, Antonio, Heráclito y Demócrito de nuestro tiempo (1594), Madrid, Diego Díaz de la Carrera, a costa de Alonso Pérez, 1641.

López Estrada, Francisco, «Documentos y juicios críticos». En Vega y CarPIO, Félix Lope de, Fuenteovejuna, Madrid, Castalia, 1969, pp. 157-160.

Madrigal, Alonso de, Cuestiones de filosofia moral, en Biblioteca de Autores españoles, tomo LXV: Obras escogidas de filósofos. Con un discurso preliminar del Excelentísimo e Ilustrísimo Señor don Adolfo de Castro, Madrid, Atlas, 1953, pp. 144-152.

MaraVAll, José Antonio, Estado moderno y mentalidad social, siglos XV a XVII. Madrid, Revista de Occidente, 1972. 
Martínez Díez, Gonzalo, «La tortura judicial en la legislación histórica española", Anuario de Historia del Derecho Español, 32 (1962), pp. 223-300.

-, "Fiscalidad en Guipúzcoa durante los siglos XIII-XIV», Anuario de Historia del Derecho Español, 44 (1974), pp. 537-617.

McGrady, Donald, «Prólogo» en Lope de Vega, Fuente Ovejuna, ed. Donald McGrady, estudio preliminar Noël Salomon, Barcelona, Crítica, 1993, pp. $1-38$.

Menéndez Pelayo, Marcelino, «Estudios sobre el teatro de Lope de Vega, IX: Crónicas y Leyendas, LXII,- Fuenteovejuna», En Obras completas, Santander, CSIC, 1949, vol, 33, pp. 172-174.

Menéndez Pidal, Faustino, La nobleza en España: ideas, estructuras, historia, Madrid, Fundación Cultural de la Nobleza Española, 2008.

Molas i Ribalta, Pere, La burguesía mercantil en la España del Antiguo Régimen, Madrid, Cátedra, 1985.

—, "Títulos de hidalguía en el Setecientos valenciano», Hidalgos et hidalguía dans l'Espagne des XVI et XVIT siècles. Théories, pratiques et représentations, París, CNRS, 1989, pp. 189-205.

Morell Peguero, Blanca, «La prueba de hidalguía en España y las Indias en el siglo XVI", Revista de Indias, 38 (1978), pp. 887-900.

Morley, S. Griswold y Bruerton, Courtney, Cronología de las comedias de Lope de Vega. Con un examen de las atribuciones dudosas, basado todo ello en un estudio de su versificación estrófica, Madrid, Gredos, 1968.

Morrás, María, "Cuadernos bibliográficos, No 5: Repertorio de obras, mss. y documentos de Alfonso de Cartagena (ca. 1384-1456), Boletín Bibliográfico de la Asociación Hispánica de Literatura Medieval, 5 (1991), pp. 213-248.

Muñoz de Bustillo, Carmen, Fuero de hidalguia: Ad pragmaticas de Toro \& Tordesillas, Bilbao, Universidad del País Vasco, 1997.

NAHARRo Quirós, Elena, «Relaciones entre dinero, trabajo y condición nobiliaria», Anuario de Historia del Derecho Español, 62 (1992), pp. 543-544.

Nicolás Sánchez, Andrés J., "Ciudadanos honrados de Zaragoza en los siglos XVII y XVIII», Hidalguía. 289 (2001), pp. 832-833.

Osma, Pedro de, Comentario a la Ética de Aristóteles, ed. José Labajos Alonso, Salamanca, Universidad Pontificia, 1996.

Padilla, Luisa María de (Condesa de Aranda), Lágrimas de la Nobleza, Zaragoza, Pedro Lanaja, 1639.

Pérez de Tudela y Velasco, María Isabel, Infanzones y caballeros: su proyección en la esfera nobiliaria castellano-leonesa (s. IX-XIII). Madrid, Universidad Complutense, 1979.

PÉrez, Joseph, "Réflexions sur l'hidalguía», en Hidalgos et hidalguía dans l'Espagne des XVI et XVIT siècles. Théories, pratiques et représentations, París, CNRS, 1989 pp. 11.-22.

Poza, Andrés de, Ad pragmáticas de Toro \& Tordesillas, sive de nobilitate in proprietate, (editado por Carmen MuÑoz de Bustillo en Fuero de hidalguia: 
ad pragmaticas de Toro \& Tordesillas, Bilbao, Universidad del País Vasco, 1997.

Rabil, Jr., Albert, Knowledge, Goodness and Power: The Debate over Nobility among Quattrocento Italian Humanists, Edited, Translated and with Introductions by Albert Rabil, Jr, Binghamton, Nueva York, Medieval \& Renaissance Texts \& Studies, 1991.

Rades y Andrada, Francisco de, Catálogo de las obligaciones que los comendadores e cavalleros, priores y otros religiosos de la Orden y Caballería de Calatrava tienen en razón de su ávito y profesión, Toledo, Juan de Ayala, 1571.

-, Francisco de, Chronica de las tres Ordenes de Cavalleria de Sanctiago, Calatrava y Alcantara: en la qual se trata de su origen y sucesso, y notables hechos en armas de los Maestres y Cavalleros en ellas y de muchos Señores de Titulo y otros Nobles que descienden de los maestres: y de muchos otros linajes de España, Toledo, Juan de Ayala, 1572.

Rades y Andrada, Francisco de, y Luna y Mendoza, Álvaro de, Definiciones de la Sagrada Religión y cavallería de Sancta María de Montesa y Sanct Jorge, filiación de la inclita milicia de Calatrava, Valencia, Pedro Patricio, 1575.

Ribeiro da Silva, Francisco, "Gentilhommes, nobles et cidadãos de Porto au XVIIe siècle: caractérisation sociale et voies d'accès», Hidalgos, hidalguía dans l'Espagne des XVI et XVII siècles. Théories, pratiques et représentations, París, CNRS, 1989, pp. 207-223.

Rodríguez Velasco, Jesús D., El debate sobre la caballería en el siglo XV: la tratadística caballeresca castellana en su marco europeo, Salamanca, Junta de Castilla y León, 1996.

RozAs, Juan Manuel, «Lope de Vega y las órdenes militares (Notas sobre el sentido histórico de su teatro)» en Estudios sobre Lope de Vega, Madrid, Cátedra, 1990, pp. 469-478.

RucquoI, Adeline, «Étre noble en Espagne aux XIV-Xvi siecles», en O.G. OeXLE; W. Paravicini (eds), Nobilitas. Funktion und Repraësentation des Adels in Alteuropa, Göttingen, Vandenhoeck \& Ruprecht, 1997, pp. 273-298.

SÁEz, Ricardo, «Hidalguía: essai de définition. Des príncipes identificateurs aux variations historiques». En Hidalgos, hidalguia dans l'Espagne des XVT et XVIT siécles. Théories, pratiques et représentations, París: CNRS, 1989, pp. 23-45.

Santa Cruz de Dueñas, Melchor de, Floresta española, Madrid, Sociedad de Bibliófilos Españoles, 1910.

Schiff, Mario, La bibliothèque du Marquis de Santillane, París, Émile Bouillon, 1905.

Solana Pujalte, Julián, «Un manuscrito semidesconocido de Juan Ginés de Sepúlveda», Cuadernos de Filología Clásica-Estudios Latinos, 7 (1994), pp. 185-213.

Soria Mesa, Enrique, La nobleza en la España Moderna. Cambio y continuidad, Madrid, Marcial Pons, 2007.

—, «La nobleza en la España Moderna. Presente y futuro de la investigación», en 
El Condado de Aranda y la nobleza española en el Antiguo Régimen, ed. María José Casus Ballester, Zaragoza, Institución Fernando el Católico, 2009, pp. 213-241.

SorIa SesÉ, Lourdes, "La hidalguía universal», Iura Vasconiae, 3 (2006), pp. 283-316.

Thompson, Ian A. A., "Neo-noble Nobility: Concepts of Hidalguía in Early Modern Castile», European History Quarterly, XV (1985), pp. 379-406.

Tiraqueau André (Andreae Tiraquelli), De nobilitate et iure primigeniorum, París, apud Iacobum Keruer, 1549.

Troyli, Placido (O.Cist), Istoria generale del Reame Di Napoli. Tomo Quarto. Parte Quarta, Nápoles, 1752.

Urcelay Gaona, Hegoi, Los Sarmiento, Condes de Salinas: Orígenes y elevación de una nueva clase señorial. Siglos XII-XVI, Bilbao, Universidad del País Vasco, 2009.

Vega y Carpio, Félix Lope de, Fuente Ovejuna, ed. Francisco López Estrada, Madrid, Castalia, 1969.

—, Félix Lope de, Fuente Ovejuna, ed. Donald McGrady; estudio preliminar de Noël Salomon, Barcelona, Crítica, 1993.

VIGón, Jorge, «Aristocracia y nobleza», Revista de estudios politicos, 31-32 (1947), pp. 145-199. 